\title{
The Diet and Haemodialysis Dyad: Three Eras, Four Open Questions and Four Paradoxes. A Narrative Review, Towards a Personalized, Patient-Centered Approach
}

\author{
Giorgina Barbara Piccoli ${ }^{1,2, *}$, Maria Rita Moio ${ }^{2}$, Antioco Fois ${ }^{3}$, Andreea Sofronie ${ }^{2}$, \\ Lurlinys Gendrot ${ }^{2}$, Gianfranca Cabiddu ${ }^{3}$, Claudia D'Alessandro ${ }^{4}$ and Adamasco Cupisti ${ }^{4}$ \\ 1 Dipartimento di Scienze Cliniche e Biologiche, University of Torino, 10100 Torino, Italy \\ 2 Nephrologie, Centre Hospitalier le Mans, Avenue Roubillard, 72000 Le Mans, France; \\ mariaritamoio@gmail.com (M.R.M.); andreea.sofronie@gmail.com (A.S.); lurlygendrot@gmail.com (L.G.) \\ 3 Nefrologia, Ospedale Brotzu, 09100 Cagliari, Italy; antiocofois@gmail.com (A.F.); \\ gianfranca.cabiddu@tin.it (G.C.) \\ 4 Nefrologia, Università di Pisa, 56100 Pisa, Italy; dalessandroclaudia@gmail.com (C.D.); \\ adamasco.cupisti@med.unipi.it (A.C.) \\ * Correspondence: gbpiccoli@yahoo.it; Tel.: +33-669-733-371
}

Received: 4 February 2017; Accepted: 31 March 2017; Published: 10 April 2017

\begin{abstract}
The history of dialysis and diet can be viewed as a series of battles waged against potential threats to patients' lives. In the early years of dialysis, potassium was identified as "the killer", and the lists patients were given of forbidden foods included most plant-derived nourishment. As soon as dialysis became more efficient and survival increased, hyperphosphatemia, was identified as the enemy, generating an even longer list of banned aliments. Conversely, the "third era" finds us combating protein-energy wasting. This review discusses four questions and four paradoxes, regarding the diet-dialysis dyad: are the "magic numbers" of nutritional requirements (calories: $30-35 \mathrm{kcal} / \mathrm{kg}$; proteins $>1.2 \mathrm{~g} / \mathrm{kg}$ ) still valid? Are the guidelines based on the metabolic needs of patients on "conventional" thrice-weekly bicarbonate dialysis applicable to different dialysis schedules, including daily dialysis or haemodiafiltration? The quantity of phosphate and potassium contained in processed and preserved foods may be significantly different from those in untreated foods: what are we eating? Is malnutrition one condition or a combination of conditions? The paradoxes: obesity is associated with higher survival in dialysis, losing weight is associated with mortality, but high BMI is a contraindication for kidney transplantation; it is difficult to limit phosphate intake when a patient is on a high-protein diet, such as the ones usually prescribed on dialysis; low serum albumin is associated with low dialysis efficiency and reduced survival, but on haemodiafiltration, high efficiency is coupled with albumin losses; banning plant derived food may limit consumption of "vascular healthy" food in a vulnerable population. Tailored approaches and agreed practices are needed so that we can identify attainable goals and pursue them in our fragile haemodialysis populations.
\end{abstract}

Keywords: diet; dialysis; haemodialysis; protein energy wasting; serum albumin Kt/V; dialysis efficiency; phosphate; survival

\section{Diet and Dialysis: A Changing Picture}

The history of dialysis and the nutritional approach in dialysis are closely connected; over time, the definition of dietary needs and limitations has reflected the major advances in renal replacement therapy and the changes that have taken place in the demography of the dialysis population. 
In this review we will attempt to contextualize some open question related to the diet and dialysis dyad. We will start by describing the three "eras" of diet-in-dialysis, each marked by a battle against a different threat to patients' lives, and each associated with different problems, restrictions and indications (Table 1).

Table 1. A simplified historical scheme of the main focuses in diets for patients on chronic haemodialysis.

\begin{tabular}{ccccc}
\hline Period * & $\begin{array}{c}\text { The Main } \\
\text { “Enemy” }\end{array}$ & The Risks & Dietary Indications & Notes \\
\hline First era & Potassium & $\begin{array}{c}\text { Hyperkalemia can } \\
\text { be deadly }\end{array}$ & $\begin{array}{c}\text { Restrictions on fruit } \\
\text { and vegetables }\end{array}$ & $\begin{array}{c}\text { Can be mitigated by } \\
\text { high dialysis efficiency } \\
\text { and acidosis control }\end{array}$ \\
\hline Second era & Phosphate & $\begin{array}{c}\text { Vascular calcification, } \\
\text { vascular ageing }\end{array}$ & $\begin{array}{c}\text { Restrictions on cheese, } \\
\text { milk and derivates }\end{array}$ & $\begin{array}{c}\text { May contrast with the } \\
\text { indications of } \\
\text { high-protein intake }\end{array}$ \\
\hline Third era & Malnutrition & $\begin{array}{c}\text { Risk of death is higher in } \\
\text { malnourished patients }\end{array}$ & $\begin{array}{c}\text { Increased protein and } \\
\text { calorie intake }\end{array}$ & $\begin{array}{c}\text { May be impossible to } \\
\text { conciliate with previous } \\
\text { restrictions }\end{array}$ \\
\hline
\end{tabular}

* The definition of each period is approximate, as each one merges with the next, and the first warnings on malnutrition are as old as dialysis itself, while we should always keep in mind the short-term risks of hyperkalemia and the long-term importance of hyperphosphatemia.

We will then discuss some questions still being debated and problems that have remained unsolved, trying to indicate the practical implications of some of the open issues and paradoxes (Table 2).

Table 2. A synthesis of the present panorama on diet and dialysis through four open questions and four paradoxes.

\begin{tabular}{|c|c|c|c|}
\hline The Questions & Pros & Cons & Comments \\
\hline $\begin{array}{l}\text { Are the nutritional } \\
\text { requirements usually cited } \\
\text { (calories: } 30-35 \mathrm{kcal} / \mathrm{kg} \text {; } \\
\text { proteins }>1.2 \mathrm{~g} / \mathrm{kg} \text { ) still } \\
\text { relevant? }\end{array}$ & $\begin{array}{l}\text { International standard } \\
\text { followed for more than } \\
40 \text { years }\end{array}$ & $\begin{array}{l}\text { The requirements were assessed } \\
\text { in a different dialysis population, } \\
\text { and may not be relevant to the } \\
\text { present one; they do not consider } \\
\text { the changes in the indications } \\
\text { given to the overall population }\end{array}$ & $\begin{array}{l}\text { There is a need for a re-assessment } \\
\text { of the requirements of elderly } \\
\text { dialysis patients }\end{array}$ \\
\hline $\begin{array}{l}\text { Are the present standards } \\
\text { of "adequate nutrition" } \\
\text { applicable to intensive } \\
\text { dialysis schedules, and to } \\
\text { haemodiafiltration? }\end{array}$ & $\begin{array}{l}\text { Simple markers such as } \\
\text { albumin level make it } \\
\text { possible to compare results, } \\
\text { and are robust enough to } \\
\text { maintain a constant } \\
\text { predictive value }\end{array}$ & $\begin{array}{l}\text { Sensibility may be lower in non } \\
\text { conventional dialysis techniques, } \\
\text { and can be affected by albumin } \\
\text { losses in haemodiafiltration }\end{array}$ & $\begin{array}{l}\text { None of the proposed evaluations } \\
\text { of malnutrition is clearly superior } \\
\text { or self-standing; results of studies } \\
\text { depend in part on the } \\
\text { definition-diagnoses chosen }\end{array}$ \\
\hline $\begin{array}{l}\text { Processed and preserved } \\
\text { food may be significantly } \\
\text { different from untreated } \\
\text { food. What are we eating? }\end{array}$ & $\begin{array}{l}\text { Nutritional approaches have } \\
\text { to be simple and basing } \\
\text { them on quantity and } \\
\text { quality may not be feasible }\end{array}$ & $\begin{array}{l}\text { Processed foods may be rich in } \\
\text { rapidly absorbable phosphate } \\
\text { and potassium }\end{array}$ & $\begin{array}{l}\text { Not acknowledging the } \\
\text { importance of additives in } \\
\text { processed and preserved foods } \\
\text { can lead to unnecessary } \\
\text { restrictions }\end{array}$ \\
\hline $\begin{array}{l}\text { Is malnutrition a single } \\
\text { disease or the result of } \\
\text { several diseases? }\end{array}$ & $\begin{array}{l}\text { The clinical signs of } \\
\text { malnutrition are universal } \\
\text { and do not depend on } \\
\text { pathogenesis }\end{array}$ & $\begin{array}{l}\text { If malnutrition is not linked to } \\
\text { poor intake but to poor clinical } \\
\text { conditions, itwill not respond } \\
\text { to therapy }\end{array}$ & $\begin{array}{l}\text { Differentiation may allow setting } \\
\text { attainable goals according to the } \\
\text { individualpatient's comorbidity }\end{array}$ \\
\hline The paradoxes & $\begin{array}{l}\text { The "logic" (overall } \\
\text { population or general data } \\
\text { in the dialysis population) }\end{array}$ & $\begin{array}{l}\text { The finding (in the dialysis } \\
\text { population or in specific dialysis } \\
\text { populations) }\end{array}$ & Comments \\
\hline Obesity and survival & $\begin{array}{l}\text { Obesity is associated with } \\
\text { lower survival in the overall } \\
\text { population }\end{array}$ & $\begin{array}{l}\text { Obesity is associated with higher } \\
\text { survival in dialysis patients; } \\
\text { losing weight is associated with } \\
\text { higher mortality on dialysis }\end{array}$ & $\begin{array}{l}\text { Obesity is often a contraindication } \\
\text { for kidney transplantation }\end{array}$ \\
\hline
\end{tabular}


Table 2. Cont.

\begin{tabular}{llll}
\hline The Questions & Pros & Cons & Comments \\
\hline $\begin{array}{l}\text { High protein intake and } \\
\text { phosphate control }\end{array}$ & $\begin{array}{l}\text { A high protein diet is } \\
\text { indicated after dialysis start }\end{array}$ & $\begin{array}{l}\text { Reduction of phosphate intake is } \\
\text { not compatible with a } \\
\text { high-protein diet }\end{array}$ & $\begin{array}{l}\text { Plant derived phosphate may be } \\
\text { less well absorbed; acidosis } \\
\text { induced by catabolism is often a } \\
\text { missing element in } \\
\text { hyperphosphatemia }\end{array}$ \\
\hline $\begin{array}{l}\text { Albumin level, Kt/V } \\
\text { and survival }\end{array}$ & $\begin{array}{l}\text { Low serum albumin and low } \\
\text { dialysis efficiency are } \\
\text { associated with } \\
\text { reduced survival }\end{array}$ & $\begin{array}{l}\text { In haemodiafiltration, high } \\
\text { efficiency is coupled with } \\
\text { significant albumin losses }\end{array}$ & $\begin{array}{l}\text { Albumin losses are incompletely } \\
\text { quantified; nutrition is probably } \\
\text { more important than high } \\
\text { efficiency in elderly or fragile } \\
\text { sarcopenic patients }\end{array}$ \\
\hline $\begin{array}{l}\text { Potassium and } \\
\text { vascular health }\end{array}$ & $\begin{array}{l}\text { Since dialysis patients are at } \\
\text { risk for hyperkalemia, } \\
\text { potassium is often restricted }\end{array}$ & $\begin{array}{l}\text { Banning plant derived food to } \\
\text { avoid hyperkalemia limits } \\
\text { consumption of "vascular healthy" } \\
\text { food in a high-risk population }\end{array}$ & $\begin{array}{l}\text { Hyperkalemia is still a rare, but } \\
\text { possible cause of death }\end{array}$ \\
\hline
\end{tabular}

\section{Dialysis and Diet: Different Enemies in Different Periods}

\subsection{The First Era: Potassium as the Killer}

Hyperkalemia and salt and water overload can prove fatal to dialysis patients, and in the early days of dialysis, acute pulmonary oedema, severe hyperkalaemia and the co-occurrence of the two conditions were frequent, and often deadly [1-3]. Due to the limited efficiency of dialysis, some dietary habits often had fatal consequences. Acidosis, only later recognized as a main cause of increases in pre-dialysis potassium, often failed to be diagnosed [4,5]. Particularly until the mid-seventies, when dialysis became more widely available, dialysis start often followed a period of low-protein diet, generally one that was far more rigid and draconian ("diet or die") than the ones now prescribed [6-12]. Growing awareness of the loss of advantage (and increase of side effects) of protein restriction after dialysis start set the stage for recommending a high-protein diet immediately after dialysis start.

Due to the high potassium content of much animal-derived food, which was preferred for its higher protein content, the patient's intake of plant-derived food was reduced, often to the point of imposing a ban on fruit and vegetables $[3,13,14]$. In the same period, patients were often advised to follow low-sodium diets, to limit thirst and weight gain, and were given long lists of forbidden foods, including most plant-derived food products [13,15-17]. This resulted in life-saving but monotonous and complex diets $[3,13]$.

Increased dialysis efficiency, together with an ageing dialysis population, with lower nutritional intake, has required that the problem be seen from a new perspective, and death due to hyperkalaemia has become less frequent; where hyperkalaemia remains as a problem, it is generally linked to acidosis, gastrointestinal bleeding, uncontrolled diabetes, or iatrogenic effects [18-21]. The present focus on dietary habits is more on avoidance of added potassium in processed foodsthan on limiting consumption of plant-derived aliments, whose importance for cardiovascular health is increasingly recognized [3,13,20-26].

\subsection{The Second Era: Phosphate as the Silent Killer}

Increased survival rates brought to light clinical problems evident only in the long term, summarized as rapid vascular aging in dialysis patients [27-32]. These conditions were sometimes called survivors' diseases, to emphasize that they had emerged only when the problem of short-term mortality had been at least partially overcome. Imbalances in the calcium-phosphate-PTH axis were identified as the main cause of rapid vascular ageing, and a high calcium-phosphate product was, and still is, associated with vascular calcification, and increased risk of death [33-39].

As a consequence, dialysis patients received a new, even longer list of foods they had to cut down on, potentially leading to the paradox of (protein) malnutrition induced by focusing on avoidance 
of phosphate-rich food. Only recently has attention focused on added phosphorus, distinguishing between processed and unprocessed foods [13,14,40-47].

Hyperphosphatemia is not only the result of a nutritional pathogenesis, as it can be the result of several conditions in which dietary restrictions are of scarce benefit, while they are frustrating for patients and may even worsen protein-energy wasting. Hyperphosphatemia may be due to:

- a low dialysis dose, which is associated with higher mortality; conversely, hyperphosphatemia is usually corrected with long dialysis sessions, or daily dialysis [48,49];

- $\quad$ uncontrolled hyperparathyroidism is not responsive to dietary measures; furthermore, it is often connected with long dialysis vintage, which is in turn associated with poor nutritional status and poor outcomes [50-53];

- a low PTH level (usually post-parathyroidectomy), is often a sign of adynamic bone disease, another condition associated with impaired nutritional status and poor outcomes [54-56];

Conversely, in thrice-weekly dialysis, low pre-dialysis phosphate levels are often a sign of protein energy wasting, and are associated with poor survival, especially if combined with hypoalbuminemia $[57,58]$. The implementation of new treatments has to some extent diverted attention from diet, while a new player, malnutrition, has emerged on the scene.

\subsection{The Third Era: Malnutrition as the Killer}

The ageing of the dialysis population and the possibility of attaining long-term survival through dialysis and transplantation, has focused attention on the central role of malnutrition both in the incident population (elderly, high comorbidity), and as a characteristic of patients with a long treatment vintage [53,55-57,59-63]. Among the biomarkers associated with survival (Kt/V, Ca-P-PTH, acidosis, etc.), the strongest is serum albumin, where a low value represents the most robust metabolic risk marker [64-73].

In keeping with the importance of nutrition in dialysis, total cholesterol, another robust marker of nutrition, is the second-most reliable marker of survival, with a " $U$ " shaped curve, as will be discussed in the case of obesity, the paradigm of reverse epidemiology [74,75]. Malnutrition is not merely the result of insufficient food intake, or of insufficient dialysis, but may reflect cardiovascular comorbidity, associated with inflammation (MIA, malnutrition, inflammation and artherosclerosis syndrome) [59,60,76-78]. As further discussed, the stronger the association with cardiovascular disease and inflammation, the harder it is to correct malnutrition: eating more may not be enough (Tables 2 and 3).

\section{Diet and Dialysis: Four Questions and Four Paradoxes}

\subsection{First Question: Are the "Magic Numbers" Still Valid?}

A series of reference numbers were progressively integrated into the indications and guidelines for the nutritional management of dialysis patients [79-86]. Some of these may prove to be too high and others too low. In their updated and extensive recent review of the revised nutritional recommendations, Biurete and coworkers discuss the changing attitudes to renal diet (and to diet in the overall population), and Kalantar-Zadeh wonders if there is anything left to eat for our patients [13]. Some of the "magic numbers" set targets that are probably too high and those which are probably too low to be attained in present clinical practice $[13,22]$ :

Targets that may be too high:

- $\quad$ Energy: $30-35 \mathrm{kcal} / \mathrm{kg}$ of dry body weight

- $\quad$ Proteins: at least $1.2 \mathrm{~g} / \mathrm{kg}$ of dry body weight

- Phosphate: 800-1000 mg/day

Targets that may be too low, especially when diuresis is partly preserved: 
- Water: as little as possible

- $\quad$ Sodium: not univocal; older guidelines recommend less than $100 \mathrm{mEq} /$ day $(5.8 \mathrm{~g}$ of $\mathrm{NaCl})$

- $\quad$ Potassuim: 2 g/day

It is interesting to note, however, that many of these often-cited numbers are either opinion based, or derived from old studies, often ones that involved a relatively small number of cases, whose characteristics no longer correspond to the profile of the patients now seen in our dialysis wards.

\subsection{Second Question: Type of Dialysis Technique: Does It Matter?}

Most nutritional indications on extracorporeal dialysis are based on the metabolic needs of "conventional" thrice-weekly bicarbonate-buffered haemodialysis [79-86]. However, there is increased acknowledgement that if dialysis is more frequent and/or sessions are longer, metabolic balance and nutritional status are more easily restored [87-91]. The option of increasing dialysis frequency should therefore be considered as a valid strategy for improving nutritional status.

A growing body of evidence on an extreme, albeit rare condition, pregnancy in dialysis patients, indirectly shows the importance of the duration and frequency of treatment in maintaining physiological balance and optimal nutritional status [92,93].

The diet-dialysis dyad is therefore modulated by dialysis prescriptions:

- $\quad$ On conventional thrice-weekly dialysis, dietary restrictions follow the need to maintain good metabolic balance (diet has to follow dialysis);

- $\quad$ On intensive dialysis schedules, higher efficiency and/or frequency may make an unrestricted diet possible (dialysis liberalizes diet);

- A particular case regards haemodiafiltration, in which high efficiency may be associated with significant protein loss, and the role of this loss in the context of dialysis-related malnutrition has still to be elucidated [94-99].

Overall, the current indications for the management of nutritional status in haemodialysis regard non-diabetic adults on thrice-weekly haemodialysis of "standard duration". Elderly and diabetic patients were not included in the studies which defined our reference numbers; however, the definition of "old age" has varied over time, from being over 50 in the 1970s, to being over 80 (sometimes over 90) now. The same indications do not necessarily apply to children, incremental dialysis, quotidian or nightly dialysis (and all variations of frequency), haemodiafiltration or haemofiltration, while controversy exists on peritoneal dialysis, which is beyond the scope of this review $[100,101]$.

\subsection{Third Question: Processed or Unprocessed Food: What Are We Actually Eating?}

The current approaches to nutritional counseling in dialysis are based on the calculation of the nutritional content of raw, unprocessed food. However, in the processed and preserved food products now widely consumed, the quantity of phosphate and potassium, and of other preservatives, taste enhancers and chemical colorants may be high, which means that a processed food product differs considerably from the natural one. In particular in the case of phosphate, it is not only the quantity that matters, but also the quality, as added inorganic phosphate is usually rapidly absorbable, and therefore more dangerous [102-111].

In this regard, the warnings on red meat are linked to those on processed meat, and the question is whether the risks are due to the additives and preservatives used or to the red meat itself [107-111].

The issue is even more complex if pesticides and trace elements are considered. For instance, fish fed with animal proteins are extremely rich in phosphate, in contrast with wild fish. However, the high content of heavy metals, mercury in particular, in large wild fish is also known, and another high risk category, that of pregnant women, are counseled to avoid eating them, as mercury can impede foetal growth. While our knowledge of such hidden dangers in the overall population is constantly 
accumulating, the little that is known about dialysis patients identifies them as a population at high risk for the chronic poisoning agents of our polluted world [112-116].

\subsection{Fourth Question: How Should Malnutrition Be Seen?}

When protein energy wasting was identified as one of the major causes of death in dialysis, the "under-dialysis syndrome" was often seen as the basis of this deadly condition $[59,60,76-78,117,118]$. The first studies on daily and nightly dialysis supported this interpretation [119-126]. The hypothesis advanced was therefore that eating better and more was possible and should be accompanied by better dialysis, and with attention to control of metabolic acidosis [117,118,127-130].

The aging of the dialysis population revealed the importance of new players: diffuse vascular disease and chronic inflammation merged with malnutrition in the malnutrition, inflammation and atherosclerosis (MIA) syndrome [59,60,76-78,131-135].

Hence, two different forms of malnutrition were identified:

- Protein energy wasting due to "poor nutrition", related to low nutrient intake, in turn linked to incomplete correction of metabolic balance, insufficient dialysis, non biocompatible membranes, poorly controlled hypertension, combined with an overly restricted diet. This form of malnutrition generally responds to nutritional intervention, after optimization of the dialysis schedule.

- $\quad$ Protein energy wasting as a result of poor clinical conditions: the prototype is the MIA syndrome, mentioned above. This type of malnutrition is less responsive to nutritional interventions and its prognosis is linked to the patient's life expectancy (Figure 1).

\section{Protein energy wasting: the final pathway of "poor" dialysis, nutrition, conditions}

\begin{tabular}{|c|}
\hline Insufficient dialysis, due to \\
errors in prescription (ex. not \\
accounting for the loss of \\
residual function), performance \\
(ex. vascular access \\
malfunction), compliance (ex. \\
skipped or shortened sessions), \\
poor tolerance (ex. hypotension, \\
post-dialysis fatigue), poor \\
biocompatibility (ex. intolerance \\
to dialysis supplies)
\end{tabular}

Insufficient calorie and protein intake, due to anorexia (linked to insufficient or inefficient dialysis and post dialysis fatigue), depression and social isolation (common in elderly patients), erroneous prescriptions (overzealous restrictions), economic constrains (common in elderly patients)

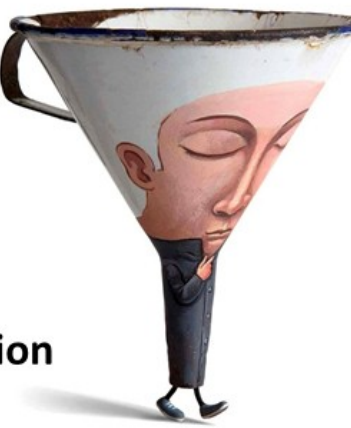

Impaired clinical conditions, high comorbidity: old age (need to individualize nutritional goals), cardiovascular disease (cause and consequence of ESRD), chronic infections (frequent and possibly oligo-symptomatic in ESRD), dialysis-related inflammation (water, vascular access) neoplasia.

\section{The common pathway of different conditions}

Figure 1. The two faces of malnutrition. 


\section{Diet and Dialysis: Four Paradoxes}

\subsection{First Paradox: Energy Intake and Obesity}

In the overall population obesity is associated with higher morbidity and mortality; hence the longer survival of obese patients in dialysis, the paradigm of reverse epidemiology, was initially surprising [136]. The effect of weight on survival on dialysis produces a u-shaped curve: in the short term, the highest risk is for underweight, malnourished patients, but obese patients, who are initially not affected by malnutrition, may pay a price in terms of mortality and comorbidity in the long run [137]. The association is observed in all dialysis populations, in chronic kidney disease and is modulated by dialysis efficiency, diabetes and sex [136-140] (Figure 2).

While life expectancy is longer after kidney transplantation, high BMI is an important contraindication for transplantation (although not an automatic disqualification in all centers), due to the poorer results obtained in obese patients [141-148]. Thus the paradoxical exclusion of obese patients, who are likely to have a longer life expectancy, from many transplant programs, underlines the many controversial facets of nutrition in dialysis [147].

The balance between the advantages and disadvantages of obesity varies across CKD phases (Figure 2). Obesity increases the risk of progression of CKD, and weight loss is advised in pre-dialysis patients. Obesity displays a survival advantage in dialysis, but represents a barrier for kidney transplantation; the indications to lose weight on dialysis are controversial, leading some authors to suggest that weight loss programs be limited to patients potentially waitlisted for kidney transplantation [138]. It is not easy for dialysis patients to lose weight and the associated benefit is not clear-cut, and may be absent [149-152]. As the risks of bariatric surgery are increasingly being recognized, the best modality for weight reduction in waitlisted dialysis patients is a matter of controversy [152].

\section{The paradox of being obese across CKD phases}

Pre dialysis

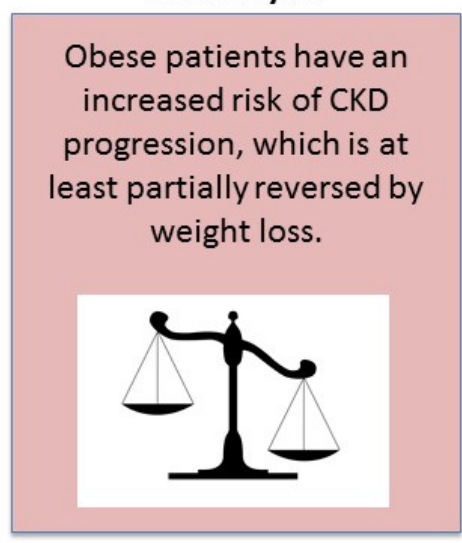

Weight loss is advised, under strict control to avoid malnutrition; bariatric surgery is associated with improved clinical parameters, but is not devoid of side effects.
Dialysis

Obese patients have a survival advantage, which may be at least partially offset by weight loss.

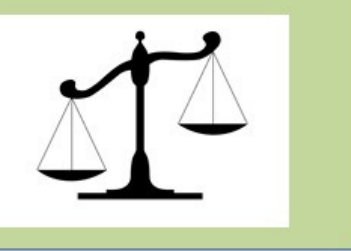

Weight loss may be required for being waitlisted for transplantation; strict control is needed to avoid malnutrition; bariatric surgery has high morbidity and conflicting results

\section{Transplantation}

Obese patients may be excluded from kidney transplantation programs; the survival disadvantage may be partially reversed by weight loss.

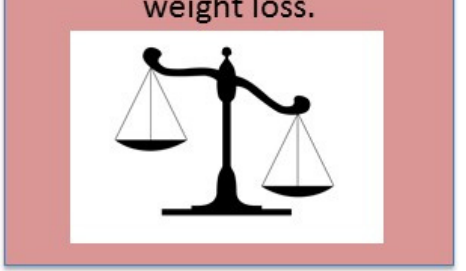

Weight loss is usually required; strict control is needed to avoid malnutrition; bariatric surgery has high morbidity but overall favorable results

Figure 2. The obesity paradox. 
The conflicting pattern of obesity-related risks across CKD phases suggests that obesity is not healthy per se, but it protects the patient from the dangers of malnutrition on dialysis in the same way as it protected our ancestors from dying in times of famine in prehistoric times [153]. In this sense, dialysis may be another example of the advantage of "thrifty" genotypes (Figure 2).

The differences between patterns of overweight/obesity suggest a tailored approach to obese dialysis patients, optimally within a flexible policy of transplant waitlisting [154,155]. Intensifying dialysis, thereby allowing for safer weight loss, is a support policy that should be considered [156].

\subsection{Second Paradox: Phosphate, Acidosis and Protein Intake}

The traditional approach involves starting a high-protein diet $(1.2-1.4 \mathrm{~g} / \mathrm{kg} /$ day of protein) immediately before renal replacement therapy, to compensate for strict pre-dialysis diets. In fact protein loss via haemodialysis, is a problem that has been known since the early years of renal replacement therapy [37-40,96-99,157].

This recommendation should be contextualized to the state of our knowledge in the late 70s and early 80 s, in a younger dialysis population with late-start dialysis, lower efficiency, pre-erythropoietin, before the catabolic effect of acidosis was fully acknowledged. This may not fully apply to our ageing dialysis population $[158,159]$.

Unfortunately high protein intake is not without side effects: fixed acid production increases on a protein rich diet (in particular one with a preponderance of food of animal origin), as does phosphate load, thus leading to a conflict between ensuring high protein intake or correcting acidosis and hyperphosphatemia [40-47].

Three points need to be underlined in this regard:

- Conflict between protein and phosphate is limited to thrice-weekly dialysis, while more frequent sessions, in particular nightly haemodialysis schedules, can remove so much phosphate that it becomes necessary to add phosphate to the dialysate [48,49,90,91,119-123].

- $\quad$ Not all phosphate is created equal: plant organic phosphate is less absorbable than phosphate in animal protein. Added inorganic phosphate, found in food preservatives, is devoid of nutritional benefit and is more easily absorbed; information on added phosphate is however often lacking from packaging [102-106].

- The role of animal-derived proteins in human nutrition has been reassessed in recent years, yet this critical analysis has not been fully extended to CKD and dialysis patients, for whom the equation "high quality protein = animal-derived protein = best protein" is still the basis for prescription, even if the interest on plant-based diets in all CKD stages is increasing [106-111,160-162].

Current approaches are more flexible regarding phosphate restriction, and are mainly aimed at avoiding added phosphate, increasingly recognized as unhealthy in CKD patients as well as in the overall population. A more liberal intake of plant-derived phosphate, together with attention to avoiding food additives, is probably compatible with good metabolic control and less need for phosphate binders, which account for a relevant portion of the pill burden in dialysis patients [160-167]. The awareness that hyperphoshatemia reflects a variety of nutritional and non-nutritional derangements can guide tailored interventions [167] (Figure 3). 


\section{Hyperphosphatemia: what do we want to find? Three cases where nutritional approaches aimed at reducing phosphate content in food may fail}

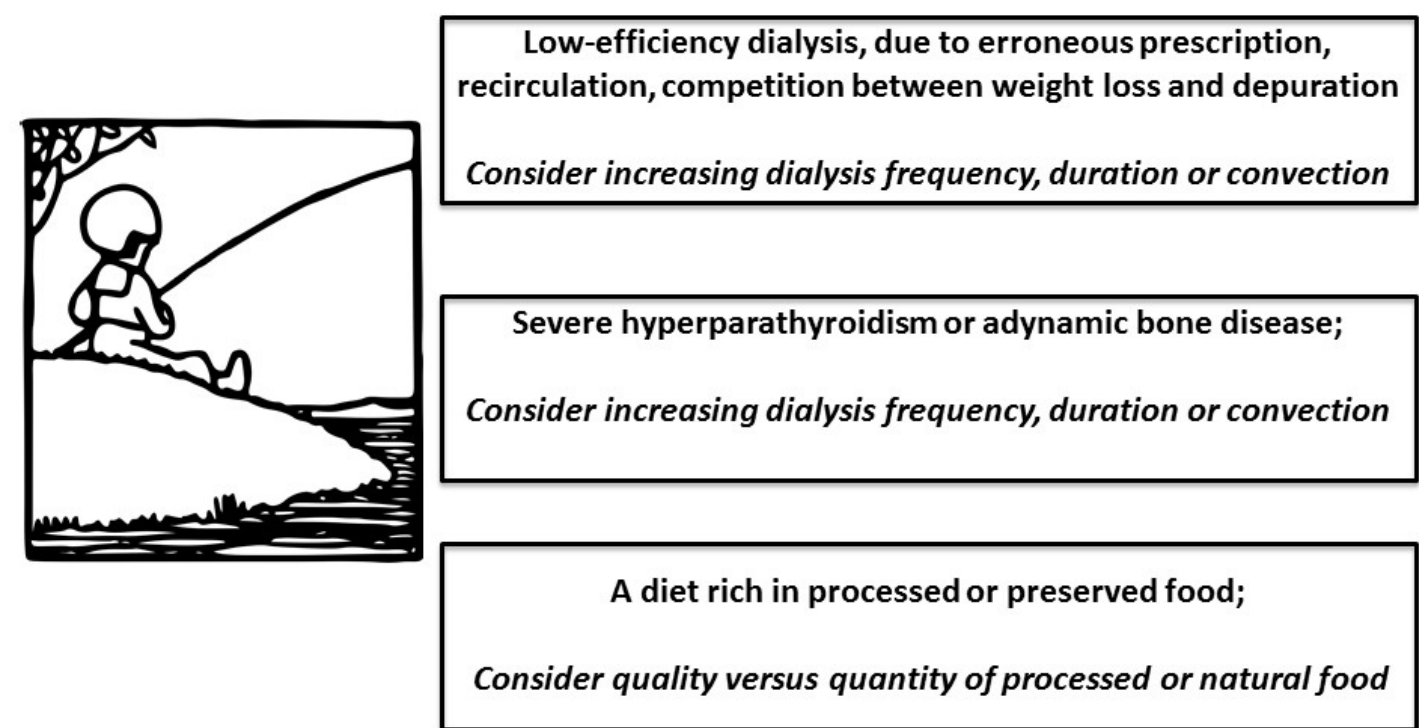

Figure 3. The phosphate, albumin, malnutrition paradox.

\subsection{Third Paradox: High-Efficiency Dialysis and Serum Albumin Levels}

For over three decades, insufficient dialysis has been associated with poor outcomes and protein energy wasting [65-70,168,169].

High-flux dialysis/haemodiafiltration, with biocompatible membranes and ultrapure water have a higher efficiency profile and are generally better tolerated, as is peritoneal dialysis [170-178]. However, one of the prices to pay is the increased loss of amino acids and of small size proteins, that can account for several grams of albumin loss per session [179-181].

This accounts for another paradoxical situation: the most biocompatible membranes, including the peritoneal one, and the highest ultrafiltration efficiency on extracorporeal dialysis are associated with lower serum albumin levels, hence with a robust marker of poor survival (Figure 4) [179-181].

Albumin losses have been quantified differently, and the heterogeneity depends on several factors:

- On extracorporeal dialysis, albumin loss depends on the type of dialysis membranes used, dialysis, hematocrit, albumin and total protein level, blood and dialysate flows; due in part to the difficulty of sampling, few studies have assessed the intersession variability of albumin losses in individual patients, in stable conditions and in specific situations, such as inflammatory states;

- No validated standardized method is available in clinical practice for dosing albumin levels at the low concentrations usually attained in the dialysate;

As will be further discussed, a missing piece of the puzzle is albumin synthesis, which is reduced in patients with chronic inflammation or severe vascular disease, once more linking nutrition and dialysis efficiency with inflammation and atherosclerosis; as some authors claim that prealbumin may be a better nutritional marker in these cases, the controversy is still open [182-184]. 


\section{Dialysis efficiency and serum albumin levels: chicken or egg? But how many chickens, how many eggs in HDF?}

\begin{abstract}
Nutritional advantages of high flux HDF :

High dialysis efficiency is correlated with improved nutritional status; improved nutritional status is correlated with better survival; HDF should correlate with improved nutritional status and better survival.

Patients with high comorbidity, including long dialysis vintage, should be treated with biocompatible membranes and efficient modalities.

HDF is a high efficiency, high tolerance dialysis modality, that should be used in fragile patients and in patients with long-term exposure to uremia.
\end{abstract}

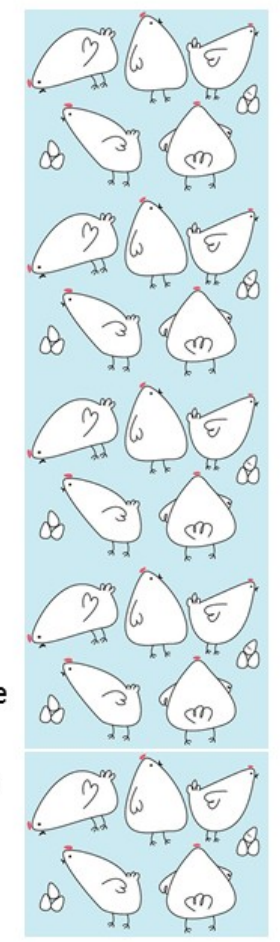

Nutritional disadvantages of high flux HDF :

Albumin level is the most robust measure of nutritional status; Impaired nutritional status heralds poor survival;

Albumin level decreases in HDF.

Patients with high comorbidity, including long dialysis vintage, are more prone to develop malnutrition and inflammation, with consequent reduction of albumin synthesis.

The albumin losses that are not compensated in fragile patients with chronic inflammation.

Figure 4. The efficiency-low albumin paradox.

\subsection{Fourth Paradox: Potassium and Vascular Health}

Seeking healthy nutrition has become fashionable: in most European countries, television and advertisements remind the public that healthy nutrition includes at least two servings of fruit and vegetables per day. The attention paid to the Mediterranean Diet, DASH and vegan-vegetarian diets underlines the importance of an adequate potassium intake for the prevention of cardiovascular diseases and highlights the risks linked to diets overly rich in animal proteins [185-192]. Similar data are observed in CKD patients, in which a "healthy" diet is associated with longer survival [193-195]. Yet it is difficult to reconcile the first killer of dialysis patients with the emerging nutritional indications. Although patients on dialysis are generally instructed to avoid fruit and vegetables, potassium is ubiquitous, and protein-rich food is often also rich in potassium. In fact, as was pointed out, limitations on potassium-rich food are not fully supported by the current literature, and a more liberal consumption of plant-derived food is probably to be advised, also because it reduces constipation (Figure 5) $[14,22,167]$. Once more, attention should be paid to the potassium contained in food preservatives rather than in fresh fruit and vegetables, while careful management of acidosis and tailored dialysis schedules can offer alternatives to dietary restrictions [14,22-26].

The use of potassium binders, potentially useful in liberalizing the "renal diet", is still matter of discussion, both with the older polystyrene resins, whose use combined with laxatives has been associated with intestinal ischemia, and with the new potassium binders, Patiromer, and Zirconium Cyclosilicate (ZS-9), the first however associated with electrolyte depletion (in particular hypomagnesemia) and the second with an increased risk of edema [196-199]. 


\title{
Plant based food is good for your heart. Potassium is dangerous for your heart...
}

\author{
PROS: plant based food in dialysis \\ patients: \\ The relationship between regular

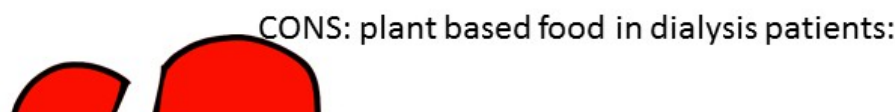 \\ consumption of fruit and vegetables and \\ cardiovascular health is of potential \\ Since fruits and vegetables are \\ importance in subjects at risk for \\ cardiovascular diseases, such as dialysis \\ patients. \\ Regular consumption of plant derived \\ food may have a protective effect on the \\ development of neoplasia, whose risk is \\ increased in dialysis patients. \\ Potassium binding resins are associated with \\ risk of intestinal ischemia, especially if \\ Plant derived, fiber rich food helps prevent \\ assumed with sorbitol or laxatives, and may \\ chelate important nutrients.
} constipation and diverticulosis.

Figure 5. The healthy heart low-potassium paradox.

\section{What This Review Did Not Address}

This review was undertaken to support the dietitian and nursing team in our hospital (Centre Hospitalier Le Mans, France) by providing a summary of the open problems and ongoing discussions in the clinical management of diet in haemodialysis patients. It does not focused on the main strategies for correcting malnutrition, briefly summarized in Table 3. It did not address many important points, including the diagnosis of malnutrition or protein energy wasting; the organization of the dietitian's support to the dialysis population; the psychological aspects of malnutrition and its relationship with depression; the role of uremic toxins; the reversibility of malnutrition after kidney transplantation and the role of macrobiotics. The acknowledgement of these limitations underlines the complexity of the issue and the need for continuous updating in this complex and evolving field.

Table 3. A schematic revision of limits and advantages of interventions to improve the nutritional status of dialysis patients.

\begin{tabular}{llll}
\hline $\begin{array}{l}\text { The Field of } \\
\text { Intervention }\end{array}$ & Intervention & Pros & Cons \\
\hline & $\begin{array}{l}\text { Increasing efficiency and tolerance by } \\
\text { increasing frequency (daily or more } \\
\text { frequent dialysis) [200-213] }\end{array}$ & $\begin{array}{l}\text { Improvement in nutritional status in } \\
\text { most of prospective studies (see also } \\
\text { pregnancy on dialysis) }\end{array}$ & $\begin{array}{l}\text { May be difficult to organize; } \\
\text { possibly higher risk of vascular } \\
\text { access problems }\end{array}$ \\
\cline { 2 - 5 } $\begin{array}{l}\text { Increasing efficiency and probably } \\
\text { optimization }\end{array}$ & $\begin{array}{l}\text { also tolerance by switching to } \\
\text { convective dialysis modalities } \\
\text { (such as high flow } \\
\text { haemodiafiltration) [214-226] }\end{array}$ & $\begin{array}{l}\text { Efficiency is associated with } \\
\text { nutritional status at least in } \\
\text { "standard patients" }\end{array}$ & $\begin{array}{l}\text { Losses may be significant in } \\
\text { elderly, malnourished patients. } \\
\text { No demonstration of nutritional } \\
\text { advantages }\end{array}$ \\
\cline { 2 - 5 } & $\begin{array}{l}\text { Decreasing losses, and preserving } \\
\text { renal function (incremental dialysis, } \\
\text { tailored dialysis) [227-242] }\end{array}$ & $\begin{array}{l}\text { Residual diuresis and residual renal } \\
\text { function are two of the most powerful } \\
\text { predictors of survival; "dialysis shock" } \\
\text { may be a cause of early death after } \\
\text { dialysis start }\end{array}$ & $\begin{array}{l}\text { Experience is still limited and } \\
\text { there is still no agreed standard }\end{array}$ \\
\hline
\end{tabular}


Table 3. Cont.

\begin{tabular}{|c|c|c|c|}
\hline $\begin{array}{l}\text { The Field of } \\
\text { Intervention }\end{array}$ & Intervention & Pros & Cons \\
\hline $\begin{array}{l}\text { Physical } \\
\text { exercise }\end{array}$ & $\begin{array}{l}\text { Physical exercise is theoretically a } \\
\text { powerful means of improving clinical } \\
\text { conditions and nutritional status in } \\
\text { patients with a chronic } \\
\text { disease [243-252] }\end{array}$ & $\begin{array}{l}\text { The best results have been reported in } \\
\text { observational studies; biases linked to } \\
\text { self-selection limit the generalization } \\
\text { of results. }\end{array}$ & $\begin{array}{l}\text { Barriers are evident in the } \\
\text { elderly population, in which } \\
\text { inactivity is often the result of } \\
\text { the same comprehensive } \\
\text { physical failure that } \\
\text { causes malnutrition }\end{array}$ \\
\hline \multirow{4}{*}{$\begin{array}{l}\text { Metabolic } \\
\text { interventions * }\end{array}$} & Anemia correction $[253,254]$ & $\begin{array}{l}\text { ESA improved quality of life, fertility } \\
\text { and sex life, issues associated with } \\
\text { nutritional status }\end{array}$ & $\begin{array}{l}\text { The association between lack of } \\
\text { response to ESAs, inflammation, } \\
\text { malnutrition and atherosclerosis } \\
\text { is part of the MIA syndrome }\end{array}$ \\
\hline & Thyroid hormones [255] & $\begin{array}{l}\text { The euthyroid sick syndrome or "low } \\
\text { T3 syndrome" is typical of } \\
\text { malnutrition/starvation }\end{array}$ & $\begin{array}{l}\text { Correction of the metabolic } \\
\text { deficit can worsen the } \\
\text { clinical picture }\end{array}$ \\
\hline & Androgen steroids [256-259] & $\begin{array}{l}\text { Recently reconsidered therapeutic } \\
\text { options include nandrolone decanoate } \\
\text { and oxymetholone, which display } \\
\text { good effects on sarcopenia }\end{array}$ & $\begin{array}{l}\text { Side effects may be relevant; this } \\
\text { treatment could be considered } \\
\text { in males with testicular failure } \\
\text { and severe sarcopenia }\end{array}$ \\
\hline & $\begin{array}{l}\text { Recombinant growth } \\
\text { hormone [260-267] }\end{array}$ & $\begin{array}{l}\text { Recombinant growth hormone is } \\
\text { routinely used in children on dialysis. } \\
\text { In adults, growth hormone is often } \\
\text { low, and the effect on severe } \\
\text { malnutrition has been favorable }\end{array}$ & $\begin{array}{l}\text { High costs and side effects limit } \\
\text { its use }\end{array}$ \\
\hline \multirow{3}{*}{$\begin{array}{l}\text { Nutritional } \\
\text { interventions }\end{array}$} & $\begin{array}{l}\text { Increasing the quantity/quality of } \\
\text { food [268-278] }\end{array}$ & $\begin{array}{l}\text { The best tool for improving } \\
\text { nutritional status, eating during } \\
\text { dialysis may be an important way to } \\
\text { improve the nutritional status of } \\
\text { dialysis patients }\end{array}$ & $\begin{array}{l}\text { If malnutrition is linked to } \\
\text { inflammation and } \\
\text { atherosclerosis, it is difficult to } \\
\text { increase the quantity or quality } \\
\text { of food }\end{array}$ \\
\hline & $\begin{array}{l}\text { Nutritional supplements } \\
\text { (oral) [279-292] }\end{array}$ & $\begin{array}{l}\text { Can be of use especially for limited } \\
\text { periods of time; specific supplements } \\
\text { for dialysis patients (poor in } \\
\text { phosphate) are also available }\end{array}$ & $\begin{array}{l}\text { Can decrease appetite for } \\
\text { "normal" food; may be less tasty } \\
\text { after a longer period }\end{array}$ \\
\hline & $\begin{array}{l}\text { Intravenous or enteral } \\
\text { supplements [293-295] }\end{array}$ & $\begin{array}{l}\text { Can help reverse acute malnutrition, } \\
\text { especially in the case of failure of the } \\
\text { two previous interventions }\end{array}$ & $\begin{array}{l}\text { May further reduce food intake; } \\
\text { and create a need for a high } \\
\text { quantity of fluids; metabolic } \\
\text { derangements are frequent in } \\
\text { the long term }\end{array}$ \\
\hline
\end{tabular}

* All major metabolic derangements, including acidosis, hyperparathyroidism and hypovitaminosis D, are associated with poor nutritional status and higher mortality in dialysis.

\section{Conclusions and Suggestions for Future Research}

Dialysis and diet are a dyad that cannot be divided if we wish to ensure the best possible metabolic balance in our patients. In taking into account the improvements in dialysis treatment and the demographic changes in the dialysis population, current dietary approaches are less restrictive than those adopted in the past, and flexible and tailor-made diet-dialysis policies are gaining interest.

The vast literature on ways that malnutrition can be prevented or reversed has often produced inconsistent results, indirectly supporting personalized interventions, and demonstrating the need for dedicated, committed and specialized multidisciplinary teams of professionals with nutritional, educational and rehabilitation skills in the core clinical management of dialysis patients.

Acknowledgments: To Susan Finnel for her careful language revision; to Mohammad Baz, for his support for the French translation of the study; to the dialysis and dietetics teams of the $\mathrm{CH}$ Le Mans for their questions, and critical contribution.

Author Contributions: G.B.P. and A.C. conceived the paper, designed it, and wrote it. M.P.M., A.F. and A.S. performed the bibliographic search, drafted the tables, and controlled the extracted data. G.C. and C.D. critically and constructively reviewed the text and participated to the revisions and writing.

Conflicts of Interest: The authors declare no conflict of interest. 


\section{References}

1. Siddiqui, J.Y.; Fitz, A.E.; Lawton, R.L.; Kirkendall, W.M. Causes of death in patients receiving long-term hemodialysis. JAMA 1970, 212, 1350-1354. [CrossRef] [PubMed]

2. Cloonan, C.C.; Gatrell, C.B.; Cushner, H.M. Emergencies in continuous dialysis patients: Diagnosis and management. Am. J. Emerg. Med. 1990, 8, 134-148. [CrossRef]

3. Quintanilla, A.P.; Weffer, M.I. Hyperkalemia in the patient on chronic dialysis. Int. J. Artif. Organs 1987, 10, 17-19. [PubMed]

4. Kopple, J.D.; Kalantar-Zadeh, K.; Mehrotra, R. Risks of chronic metabolic acidosis in patients with chronic kidney disease. Kidney Int. Suppl. 2005, 67, S21-S27. [CrossRef] [PubMed]

5. Sanghavi, S.; Whiting, S.; Uribarri, J. Potassium balance in dialysis patients. Semin. Dial. 2013, 26, 597-603. [CrossRef] [PubMed]

6. Giovannetti, S.; Maggiore, Q. A low-nitrogen diet with proteins of high biological value for severe chronic uraemia. Lancet 1964, 1, 1000-1003.

7. Berlyne, G.M.; Shaw, A.B.; Nilwarangkur, S. Dietary treatment of chronic renal failure. Experiences with a modified Giovannetti diet. Nephron 1965, 2, 129-147. [CrossRef] [PubMed]

8. Silvererg, D.S.; Hunt, J.C. Dietary considerations in treating chronic renal failure. J. Am. Diet. Assoc. 1966, 49, 425-427. [PubMed]

9. Mitch, W.E.; Abras, E.; Walser, M. Long-term effects of a new ketoacid-amino acid supplement in patients with chronic renal failure. Kidney Int. 1982, 22, 48-53. [CrossRef] [PubMed]

10. Fouque, D.; Laville, M.; Boissel, J.P.; Chifflet, R.; Labeeuw, M.; Zech, P.Y. Controlled low protein diets in chronic renal insufficiency: Meta-analysis. BMJ 1992, 304, 216-220. [CrossRef] [PubMed]

11. Mitch, W.E.; Remuzzi, G. Diets for patients with chronic kidney disease, should we reconsider? BMC Nephrol. 2016, 17, 80. [CrossRef] [PubMed]

12. Kovesdy, C.P.; Kalantar-Zadeh, K. Back to the future, restricted protein intake for conservative management of CKD, triple goals of renoprotection, uremia mitigation, and nutritional health. Int. Urol. Nephrol. 2016, 48, 725-729. [CrossRef] [PubMed]

13. Kalantar-Zadeh, K.; Tortorici, A.R.; Chen, J.L.; Kamgar, M.; Lau, W.L.; Moradi, H.; Rhee, C.M.; Streja, E.; Kovesdy, C.P. Dietary restrictions in dialysis patients, is there anything left to eat? Semin. Dial. 2015, 28, 159-168. [CrossRef] [PubMed]

14. St-Jules, D.E.; Goldfarb, D.S.; Sevick, M.A. Nutrient non-equivalence, does restricting high-potassium plant foods help to prevent hyperkalemia in hemodialysis patients? J. Ren. Nutr. 2016, 26, 282-287. [CrossRef] [PubMed]

15. Bakke, J.; Goodwin, L.; Okiyama, T. Sodium-restricted diets for dialysis patients. Hospitals 1966, 40, 76-81. [PubMed]

16. Blumberg, A.; Nelp, W.B.; Hegstrom, R.M.; Scribner, B.H. Extracellular volume in patients with chronic renal disease treated for hypertension by sodium restriction. Lancet 1967, 2, 69-73. [CrossRef]

17. Comity, C.M. Long-term dietary management of dialysis patients. II. Composition and planning of the diet and patient education. J. Am. Diet. Assoc. 1968, 53, 445-449. [PubMed]

18. Rachoin, J.S.; Weisberg, L.S. How should dialysis fluid be individualized for the chronic hemodialysis patient? Potassium. Semin. Dial. 2008, 21, 223-225. [CrossRef] [PubMed]

19. Pani, A.; Floris, M.; Rosner, M.H.; Ronco, C. Hyperkalemia in hemodialysis patients. Semin. Dial. 2014, 27, 571-576. [CrossRef] [PubMed]

20. Kovesdy, C.P.; Regidor, D.L.; Mehrotra, R.; Jing, J.; McAllister, C.J.; Greenland, S.; Kopple, J.D.; Kalantar-Zadeh, K. Serum and dialysate potassium concentrations and survival in hemodialysis patients. Clin. J. Am. Soc. Nephrol. 2007, 2, 999-1007. [CrossRef] [PubMed]

21. Ahmed, J.; Weisberg, L.S. Hyperkalemia in dialysis patients. Semin. Dial. 2001, 14, 348-356. [CrossRef] [PubMed]

22. Biruete, A.; Jeong, J.H.; Barnes, J.L.; Wilund, K.R. Modified Nutritional Recommendations to Improve Dietary Patterns and Outcomes in Hemodialysis Patients. J. Ren. Nutr. 2017, 27, 62-70. [CrossRef] [PubMed]

23. Sherman, R.A.; Mehta, O. Phosphorus and potassium content of enhanced meat and poultry products, implications for patients who receive dialysis. Clin. J. Am. Soc. Nephrol. 2009, 4, 1370-1373. 
24. Curtis, C.J.; Niederman, S.A.; Kansagra, S.M. Availability of potassium on the nutrition facts panel of US packaged foods. JAMA Intern. Med. 2013, 173, 828-829. [CrossRef] [PubMed]

25. Stover, J. Non-dietary causes of hyperkalemia. Nephrol. Nurs. J. 2006, 33, 221-222. [PubMed]

26. Noori, N.; Kalantar-Zadeh, K.; Kovesdy, C.P.; Murali, S.B.; Bross, R.; Nissenson, A.R.; Kopple, J.D. Dietary potassium intake and mortality in long-term hemodialysis patients. Am. J. Kidney Dis. 2010, 56, 338-347. [CrossRef] [PubMed]

27. Burrowes, J.D.; Larive, B.; Cockram, D.B.; Dwyer, J.; Kusek, J.W.; McLeroy, S.; Poole, D.; Rocco, M.V.; Hemodialysis (HEMO) Study Group. Effects of dietary intake, appetite, and eating habits on dialysis and non-dialysis treatment days in hemodialysis patients, cross-sectional results from the HEMO study. J. Ren. Nutr. 2003, 13, 191-198. [CrossRef]

28. Charney, D.I.; Walton, D.F.; Cheung, A.K. Atherosclerosis in chronic renal failure. Curr. Opin. Nephrol. Hypertens. 1993, 2, 876-882. [CrossRef] [PubMed]

29. Huysmans, K.; Lins, R.L.; Daelemans, R.; Zachée, P.; De Broe, M. Hypertension and accelerated atherosclerosis in endstage renal disease. J. Nephrol. 1998, 11, 185-195. [PubMed]

30. Amann, K.; Tyralla, K.; Gross, M.L.; Eifert, T.; Adamczak, M.; Ritz, E. Special characteristics of atherosclerosis in chronic renal failure. Clin. Nephrol. 2003, 60, S13-S21. [PubMed]

31. Shanahan, C.M. Mechanisms of vascular calcification in CKD-evidence for premature ageing? Nat. Rev. Nephrol. 2013, 9, 661-670. [CrossRef] [PubMed]

32. Piccoli, G.B.; Mezza, E.; Anania, P.; Iadarola, A.M.; Vischi, M.; Torazza, M.C.; Fop, F.; Guarena, C.; Martina, G.; Messina, M.; et al. Patients on renal replacement therapy for 20 or more years, a clinical profile. Nephrol. Dial. Transplant. 2002, 17, 1440-1449. [CrossRef] [PubMed]

33. Block, G.A.; Hulbert-Shearon, T.E.; Levin, N.W.; Port, F.K. Association of serum phosphorus and calcium $\times$ phosphate product with mortality risk in chronic hemodialysis patients, a national study. Am. J. Kidney Dis. 1998, 31, 607-617. [CrossRef] [PubMed]

34. Block, G.A.; Port, F.K. Re-evaluation of risks associated with hyperphosphatemia and hyperparathyroidism in dialysis patients, recommendations for a change in management. Am. J. Kidney Dis. 2000, 35, 1226-1237. [CrossRef]

35. Ganesh, S.K.; Stack, A.G.; Levin, N.W.; Hulbert-Shearon, T.; Port, F.K. Association of elevated serum PO(4), $\mathrm{Ca} \times \mathrm{PO}(4)$ product, and parathyroid hormone with cardiac mortality risk in chronic hemodialysis patients. J. Am. Soc. Nephrol. 2001, 12, 2131-2138. [PubMed]

36. Tentori, F.; Blayney, M.J.; Albert, J.M.; Gillespie, B.W.; Kerr, P.G.; Bommer, J.; Young, E.W.; Akizawa, T.; Akiba, T.; Pisoni, R.L.; et al. Mortality risk for dialysis patients with different levels of serum calcium, phosphorus, and PTH, the Dialysis Outcomes and Practice Patterns Study (DOPPS). Am. J. Kidney Dis. 2008, 52,519-530. [CrossRef] [PubMed]

37. Shroff, R. Phosphate is a vascular toxin. Pediatr. Nephrol. 2013, 28, 583-593. [CrossRef] [PubMed]

38. Rivara, M.B.; Ravel, V.; Kalantar-Zadeh, K.; Streja, E.; Lau, W.L.; Nissenson, A.R.; Kestenbaum, B.; de Boer, I.H.; Himmelfarb, J.; Mehrotra, R. Uncorrected and Albumin-Corrected Calcium, Phosphorus, and Mortality in Patients Undergoing Maintenance Dialysis. J. Am. Soc. Nephrol. 2015, 26, 1671-1681. [CrossRef] [PubMed]

39. Sherman, R.A. Hyperphosphatemia in Dialysis Patients, Beyond Nonadherence to Diet and Binders. Am. J. Kidney Dis. 2016, 67, 182-186. [CrossRef] [PubMed]

40. Lynch, K.E.; Lynch, R.; Curhan, G.C.; Brunelli, S.M. Prescribed dietary phosphate restriction and survival among hemodialysis patients. Clin. J. Am. Soc. Nephrol. 2011, 6, 620-629. [CrossRef] [PubMed]

41. Mathewson, A.M.; Fouque, D.; Toft, A.J. Dietary phosphate assessment in dialysis patients. J. Ren. Nutr. 2010, 20, 351-358. [CrossRef] [PubMed]

42. Sherman, R.A.; Mehta, O. Dietary phosphorus restriction in dialysis patients, potential impact of processed meat, poultry, and fish products as protein sources. Am. J. Kidney Dis. 2009, 54, 18-23. [CrossRef] [PubMed]

43. Cuppari, L.; Kamimura, M.A. Dialysis, Dietary phosphorus restriction, changing the paradigm? Nat. Rev. Nephrol. 2011, 7, 252-253. [CrossRef] [PubMed]

44. Fouque, D.; Horne, R.; Cozzolino, M.; Kalantar-Zadeh, K. Balancing nutrition and serum phosphorus in maintenance dialysis. Am. J. Kidney Dis. 2014, 64, 143-150. [CrossRef] [PubMed] 
45. Kalantar-Zadeh, K.; Gutekunst, L.; Mehrotra, R.; Kovesdy, C.P.; Bross, R.; Shinaberger, C.S.; Noori, N.; Hirschberg, R.; Benner, D.; Nissenson, A.R.; et al. Understanding sources of dietary phosphorus in the treatment of patients with chronic kidney disease. Clin. J. Am. Soc. Nephrol. 2010, 5, 519-530. [CrossRef] [PubMed]

46. Shinaberger, C.S.; Greenland, S.; Kopple, J.D.; Van Wyck, D.; Mehrotra, R.; Kovesdy, C.P.; Kalantar-Zadeh, K. Is controlling phosphorus by decreasing dietary protein intake beneficial or harmful in persons with chronic kidney disease? Am. J. Clin. Nutr. 2008, 88, 1511-1518. [CrossRef] [PubMed]

47. D'Alessandro, C.; Piccoli, G.B.; Cupisti, A. The "phosphorus pyramid": A visual tool for dietary phosphate management in dialysis and CKD patients. BMC Nephrol. 2015, 16, 9. [CrossRef] [PubMed]

48. Copland, M.; Komenda, P.; Weinhandl, E.D.; McCullough, P.A.; Morfin, J.A. Intensive Hemodialysis, Mineral and Bone Disorder, and Phosphate Binder Use. Am. J. Kidney Dis. 2016, 68, S24-S32. [CrossRef] [PubMed]

49. Daugirdas, J.T.; Chertow, G.M.; Larive, B.; Pierratos, A.; Greene, T.; Ayus, J.C.; Kendrick, C.A.; James, S.H.; Miller, B.W.; Schulman, G.; et al. Effects of frequent hemodialysis on measures of CKD mineral and bone disorder. J. Am. Soc. Nephrol. 2012, 23, 727-738. [CrossRef] [PubMed]

50. Chertow, G.M.; Johansen, K.L.; Lew, N.; Lazarus, J.M.; Lowrie, E.G. Vintage, nutritional status, and survival in hemodialysis patients. Kidney Int. 2000, 57, 1176-1181. [CrossRef] [PubMed]

51. Avram, M.M.; Mittman, N.; Fein, P.A.; Agahiu, S.; Hartman, W.; Chattopadhyay, N.; Matza, B. Dialysis vintage, body composition, and survival in peritoneal dialysis patients. Adv. Perit. Dial. 2012, 28, 144-147. [PubMed]

52. Chauhan, V.; Chauhan, C.G. Dialysis vintage could confound survival trends in ESRD patients. Am. J. Kidney Dis. 2014, 64, 156. [CrossRef] [PubMed]

53. Drechsler, C.; Krane, V.; Grootendorst, D.C.; Ritz, E.; Winkler, K.; März, W.; Dekker, F.; Wanner, C.; German Diabetes and Dialysis Study Investigators. The association between parathyroid hormone and mortality in dialysis patients is modified by wasting. Nephrol. Dial. Transplant. 2009, 24, 3151-3157. [CrossRef] [PubMed]

54. Frazão, J.M.; Martins, P. Adynamic bone disease, clinical and therapeutic implications. Curr. Opin. Nephrol. Hypertens. 2009, 18, 303-307. [CrossRef] [PubMed]

55. Dukkipati, R.; Kovesdy, C.P.; Colman, S.; Budoff, M.J.; Nissenson, A.R.; Sprague, S.M.; Kopple, J.D.; Kalantar-Zadeh, K. Association of relatively low serum parathyroid hormone with malnutrition-inflammation complex and survival in maintenance hemodialysis patients. J. Ren. Nutr. 2010, 20, 243-254. [CrossRef] [PubMed]

56. Jean, G.; Lataillade, D.; Genet, L.; Legrand, E.; Kuentz, F.; Moreau-Gaudry, X.; Fouque, D.; ARNOS study investigators. Association between very low PTH levels and poor survival rates in haemodialysis patients, results from the French ARNOS cohort. Nephron Clin. Pract. 2011, 118, c211-c216. [CrossRef] [PubMed]

57. Lertdumrongluk, P.; Rhee, C.M.; Park, J.; Lau, W.L.; Moradi, H.; Jing, J.; Molnar, M.Z.; Brunelli, S.M.; Nissenson, A.R.; Kovesdy, C.P.; et al. Association of serum phosphorus concentration with mortality in elderly and nonelderly hemodialysis patients. J. Ren. Nutr. 2013, 23, 411-421. [CrossRef] [PubMed]

58. Zitt, E.; Lamina, C.; Sturm, G.; Knoll, F.; Lins, F.; Freistätter, O.; Kronenberg, F.; Lhotta, K.; Neyer, U. Interaction of time-varying albumin and phosphorus on mortality in incident dialysis patients. Clin. J. Am. Soc. Nephrol. 2011, 6, 2650-2656. [CrossRef] [PubMed]

59. Stenvinkel, P.; Heimbürger, O.; Paultre, F.; Diczfalusy, U.; Wang, T.; Berglund, L.; Jogestrand, T. Strong association between malnutrition, inflammation, and atherosclerosis in chronic renal failure. Kidney Int. 1999, 55, 1899-1911. [CrossRef] [PubMed]

60. Kalantar-Zadeh, K.; Stenvinkel, P.; Pillon, L.; Kopple, J.D. Inflammation and nutrition in renal insufficiency. Adv. Ren. Replace Ther. 2003, 10, 155-169. [CrossRef] [PubMed]

61. Komatsu, M.; Okazaki, M.; Tsuchiya, K.; Kawaguchi, H.; Nitta, K. Geriatric Nutritional Risk Index Is a Simple Predictor of Mortality in Chronic Hemodialysis Patients. Blood Purif. 2015, 39, 281-287.

62. Panichi, V.; Cupisti, A.; Rosati, A.; Di Giorgio, A.; Scatena, A.; Menconi, O.; Bozzoli, L.; Bottai, A. Geriatric nutritional risk index is a strong predictor of mortality in hemodialysis patients, data from the Riscavid cohort. J. Nephrol. 2014, 27, 193-201. [CrossRef] [PubMed]

63. Pereira, R.A.; Cordeiro, A.C.; Avesani, C.M.; Carrero, J.J.; Lindholm, B.; Amparo, F.C.; Amodeo, C.; Cuppari, L.; Kamimura, M.A. Sarcopenia in chronic kidney disease on conservative therapy, prevalence and association with mortality. Nephrol. Dial. Transplant. 2015, 30, 1718-1725. [CrossRef] [PubMed] 
64. Fish, J.C.; Remmers, A.R., Jr.; Lindley, J.D.; Sarles, H.E. Albumin kinetics and nutritional rehabilitation in the unattended home-dialysis patient. N. Engl. J. Med. 1972, 287, 478-481. [CrossRef] [PubMed]

65. Blagg, C.R.; Scribner, B.H. Diet, drugs and dialysis in the management of chronic renal failure. Prog. Biochem. Pharmacol. 1972, 7, 452-497. [PubMed]

66. Mackenzie, J.C. Nutrition and dialysis. World Rev. Nutr. Diet. 1971, 13, 194-276. [PubMed]

67. Ginn, H.E. Nutritional aspects of chronic renal dialysis. South. Med. J. 1969, 62, 1471-1476. [CrossRef] [PubMed]

68. Lowrie, E.G.; Lew, N.L. Death risk in hemodialysis patients, the predictive value of commonly measured variables and an evaluation of death rate differences between facilities. Am. J. Kidney Dis 1990, 15, 458-482. [CrossRef]

69. Kaminski, M.V., Jr.; Lowrie, E.G.; Rosenblatt, S.G.; Haase, T. Malnutrition is lethal, diagnosable, and treatable in ESRD patients. Transplant. Proc. 1991, 23, 1810-1815. [PubMed]

70. Owen, W.F., Jr.; Lew, N.L.; Liu, Y.; Lowrie, E.G.; Lazarus, J.M. The urea reduction ratio and serum albumin concentration as predictors of mortality in patients undergoing hemodialysis. N. Engl. J. Med. 1993, 329, 1001-1006. [CrossRef] [PubMed]

71. Goldwasser, P.; Mittman, N.; Antignani, A.; Burrell, D.; Michel, M.A.; Collier, J.; Avram, M.M. Predictors of mortality in hemodialysis patients. J. Am. Soc. Nephrol. 1993, 9, 1613-1622.

72. Avram, M.M.; Bonomini, L.V.; Sreedhara, R.; Mittman, N. Predictive value of nutritional markers (albumin, creatinine, cholesterol, and hematocrit) for patients on dialysis for up to 30 years. Am. J. Kidney Dis. 1996, 28, 910-917. [CrossRef]

73. Maggiore, Q.; Nigrelli, S.; Ciccarelli, C.; Grimaldi, C.; Rossi, G.A.; Michelassi, C. Nutritional and prognostic correlates of bioimpedance indexes in hemodialysis patients. Kidney Int. 1996, 50, 2103-2108. [CrossRef] [PubMed]

74. Kalantar-Zadeh, K.; Block, G.; Humphreys, M.H.; Kopple, J.D. Reverse epidemiology of cardiovascular risk factors in maintenance dialysis patients. Kidney Int. 2003, 63, 793-808. [CrossRef] [PubMed]

75. Kalantar-Zadeh, K.; Kilpatrick, R.D.; Kuwae, N.; Wu, D.Y. Reverse epidemiology, a spurious hypothesis or a hardcore reality? Blood Purif. 2005, 23, 57-63. [CrossRef] [PubMed]

76. Lowrie, E.G. Acute-phase inflammatory process contributes to malnutrition, anemia, and possibly other abnormalities in dialysis patients. Am. J. Kidney Dis. 1998, 32, S105-S112. [CrossRef]

77. Stenvinkel, P. Inflammatory and atherosclerotic interactions in the depleted uremic patient. Blood Purif. 2001, 19, 53-61. [CrossRef] [PubMed]

78. Kalantar-Zadeh, K.; Kopple, J.D.; Humphreys, M.H.; Block, G. Comparing outcome predictability of markers of malnutrition-inflammation complex syndrome in haemodialysis patients. Nephrol. Dial. Transplant. 2004, 19, 1507-1519. [CrossRef] [PubMed]

79. NKF. KDOQI-Clinical Practice Guidelines for Hemodialysis Adequacy. Am. J. Kidney Dis. 2006, 48, S2-S90.

80. Beto, J.A.; Ramirez, W.E.; Bansal, V.K. Medical nutrition therapy in adults with chronic kidney disease, integrating evidence and consensus into practice for the generalist registered dietitian nutritionist. J. Acad. Nutr. Diet. 2014, 114, 1077-1087. [CrossRef] [PubMed]

81. Trudel, T.; McCune, A.; Donahue, K.; Zuberbuhler, L.; Farmer, A.; Mager, D. Variables influencing adoption of practice-based guidelines in Canadian renal dietetic practice. J. Ren. Nutr. 2010, 20, 235-242. [CrossRef] [PubMed]

82. Toigo, G.; Aparicio, M.; Attman, P.O.; Cano, N.; Cianciaruso, B.; Engel, B.; Fouque, D.; Heidland, A.; Teplan, V.; Wanner, C. Expert working group report on nutrition in adult patients with renal insufficiency (Part 2 of 2). Clin. Nutr. 2000, 19, 281-291. [CrossRef] [PubMed]

83. Fouque, D.; Vennegoor, M.; ter Wee, P.; Wanner, C.; Basci, A.; Canaud, B.; Haage, P.; Konner, K.; Kooman, J.; Martin-Malo, A.; et al. EBPG guideline on nutrition. Nephrol. Dial. Transplant. 2007, 22, ii45-ii87. [CrossRef] [PubMed]

84. Combe, C.; McCullough, K.P.; Asano, Y.; Ginsberg, N.; Maroni, B.J.; Pifer, T.B. Kidney Disease Outcomes Quality Initiative (K/DOQI) and the Dialysis Outcomes and Practice Patterns Study (DOPPS), nutrition guidelines, indicators, and practices. Am. J. Kidney Dis 2004, 44, 39-46. [CrossRef]

85. Hecking, E.; Bragg-Gresham, J.L.; Rayner, H.C.; Pisoni, R.L.; Andreucci, V.E.; Combe, C.; Greenwood, R.; McCullough, K.; Feldman, H.I.; Young, E.W.; et al. Haemodialysis prescription, adherence and nutritional indicators in five European countries, results from the Dialysis Outcomes and Practice Patterns Study (DOPPS). Nephrol. Dial. Transplant. 2004, 19, 100-107. [CrossRef] [PubMed] 
86. Palmer, S.C.; Hanson, C.S.; Craig, J.C.; Strippoli, G.F.; Ruospo, M.; Campbell, K.; Johnson, D.W.; Tong, A. Dietary and fluid restrictions in CKD: A thematic synthesis of patient views from qualitative studies. Am. J. Kidney Dis. 2015, 65, 559-573. [CrossRef] [PubMed]

87. Galland, R.; Traeger, J. Short daily hemodialysis and nutritional status in patients with chronic renal failure. Semin. Dial. 2004, 17, 104-108. [CrossRef] [PubMed]

88. Spanner, E.; Suri, R.; Heidenheim, A.P.; Lindsay, R.M. The impact of quotidian hemodialysis on nutrition. Am. J. Kidney Dis. 2003, 42, 30-35. [CrossRef]

89. Kjellstrand, C.; Buoncristiani, U.; Ting, G.; Traeger, J.; Piccoli, G.B.; Sibai-Galland, R.; Young, B.A.; Blagg, C.R. Survival with short-daily hemodialysis, association of time, site, and dose of dialysis. Hemodial. Int. 2010, 14, 464-470. [CrossRef] [PubMed]

90. Ipema, K.J.; Struijk, S.; van der Velden, A.; Westerhuis, R.; van der Schans, C.P.; Gaillard, C.A.J.M.; Krijnen, W.P.; Franssen, C.F.M. Nutritional Status in Nocturnal Hemodialysis Patients-A Systematic Review with Meta-Analysis. PLoS ONE 2016, 11, e0157621. [CrossRef] [PubMed]

91. Demirci, C.; Ozkahya, M.; Demirci, M.S.; Asci, G.; Kose, T.; Colak, T.; Duman, S.; Toz, H.; Ergin, P.; Adam, S.M.; et al. Effects of three times weekly eight-hour nocturnal hemodialysis on volume and nutritional status. Am. J. Nephrol. 2013, 37, 559-567. [CrossRef] [PubMed]

92. Piccoli, G.B.; Minelli, F.; Versino, E.; Cabiddu, G.; Attini, R.; Vigotti, F.N.; Rolfo, A.; Giuffrida, D.; Colombi, N.; Pani, A.; Todros, T. Pregnancy in dialysis patients in the new millennium: A systematic review and meta-regression analysis correlating dialysis schedules and pregnancy outcomes. Nephrol. Dial. Transplant. 2016, 31, 1915-1934. [CrossRef] [PubMed]

93. Hladunewich, M.; Schatell, D. Intensive dialysis and pregnancy. Hemodial. Int. 2016, 20, 339-348. [CrossRef] [PubMed]

94. Weng, C.H.; Hsu, C.W.; Hu, C.C.; Yen, T.H.; Huang, W.H. Association Between Hemodiafiltration and Hypoalbuminemia in Middle-Age Hemodialysis Patients. Medicine 2016, 95, e3334. [CrossRef] [PubMed]

95. Fournier, A.; Birmelé, B.; François, M.; Prat, L.; Halimi, J.M. Factors associated with albumin loss in post-dilution hemodiafiltration and nutritional consequences. Int. J. Artif. Organs 2015, 38, 76-82. [CrossRef] [PubMed]

96. Orasan, R.A.; Patiu, I.M.; Anghel, D.; Bejan, C.; Iosub, L.; Totolici, C.; Pop, M.; Turcea, C.; Teodoru, C.; Orasan, O.H.; et al. Variation of clinical and laboratory features in chronic dialysis patients treated with high-flux hemodialysis after switching to online hemodiafiltration. Int. Urol. Nephrol. 2013, 45, 1415-1422. [CrossRef] [PubMed]

97. Cross, J.; Davenport, A. Does online hemodiafiltration lead to reduction in trace elements and vitamins? Hemodial. Int. 2011, 15, 509-514. [CrossRef] [PubMed]

98. Masakane, I. Choice of modality with the use of high-performance membrane and evaluation for clinical effects. Contrib. Nephrol. 2011, 173, 84-94. [PubMed]

99. Vega, A.; Quiroga, B.; Abad, S.; Aragoncillo, I.; Arroyo, D.; Panizo, N.; López-Gómez, J.M. Albumin leakage in online hemodiafiltration, more convective transport, more losses? Ther. Apher. Dial. 2015, 19, 267-271. [CrossRef] [PubMed]

100. Guest, S. Hypoalbuminemia in peritoneal dialysis patients. Adv. Perit. Dial. 2013, 29, 55-60. [PubMed]

101. Rippe, B.; Öberg, C.M. Albumin Turnover in Peritoneal and Hemodialysis. Semin. Dial. 2016, 29, 458-462. [CrossRef] [PubMed]

102. Sullivan, C.; Sayre, S.S.; Leon, J.B.; Machekano, R.; Love, T.E.; Porter, D.; Marbury, M.; Sehgal, A.R. Effect of food additives on hyperphosphatemia among patients with end-stage renal disease, a randomized controlled trial. JAMA 2009, 301, 629-635. [CrossRef] [PubMed]

103. Sarathy, S.; Sullivan, C.; Leon, J.B.; Sehgal, A.R. Fast food, phosphorus-containing additives, and the renal diet. J. Ren. Nutr. 2008, 18, 466-470. [CrossRef] [PubMed]

104. Cupisti, A.; Kalantar-Zadeh, K. Management of natural and added dietary phosphorus burden in kidney disease. Semin. Nephrol. 2013, 33, 180-190. [CrossRef] [PubMed]

105. Shutto, Y.; Shimada, M.; Kitajima, M.; Yamabe, H.; Razzaque, M.S. Lack of awareness among future medical professionals about the risk of consuming hidden phosphate-containing processed food and drinks. PLoS ONE 2011, 6, e29105. [CrossRef] [PubMed] 
106. Benini, O.; D'Alessandro, C.; Gianfaldoni, D.; Cupisti, A. Extra-phosphate load from food additives in commonly eaten foods, a real and insidious danger for renal patients. J. Ren. Nutr. 2011, 21, 303-308. [CrossRef] [PubMed]

107. Ornish, D. Holy Cow! What's good for you is good for our planet, comment on "Red Meat Consumption and Mortality". Arch. Intern. Med. 2012, 172, 563-564. [CrossRef] [PubMed]

108. Pan, A.; Sun, Q.; Bernstein, A.M.; Aragoncillo, I.; Arroyo, D.; Panizo, N.; López-Gómez, J.M. Red meat consumption and mortality, results from 2 prospective cohort studies. Arch. Intern. Med. 2012, 172, 555-563. [PubMed]

109. Larsson, S.C.; Orsini, N. Red meat and processed meat consumption and all-cause mortality, a meta-analysis. Am. J. Epidemiol. 2014, 179, 282-289. [CrossRef] [PubMed]

110. Abete, I.; Romaguera, D.; Vieira, A.R.; Lopez de Munain, A.; Norat, T. Association between total, processed, red and white meat consumption and all-cause, CVD and IHD mortality, a meta-analysis of cohort studies. Br. J. Nutr. 2014, 112, 762-775. [CrossRef] [PubMed]

111. Wang, X.; Lin, X.; Ouyang, Y.Y.; Liu, J.; Zhao, G.; Pan, A.; Hu, F.B. Red and processed meat consumption and mortality, dose-response meta-analysis of prospective cohort studies. Public Health Nutr. 2016, 19, 893-905. [CrossRef] [PubMed]

112. Downer, M.K.; Martínez-González, M.A.; Gea, A.; Stampfer, M.; Warnberg, J.; Ruiz-Canela, M.; Salas-Salvadó, J.; Corella, D.; Ros, E.; Fitó, M.; et al. Mercury exposure and risk of cardiovascular disease: A nested case-control study in the PREDIMED (PREvention with MEDiterranean Diet) study. BMC Cardiovasc. Disord. 2017, 17, 9. [CrossRef] [PubMed]

113. Mozaffarian, D. Fish, mercury, selenium and cardiovascular risk, current evidence and unanswered questions. Int. J. Environ. Res. Public Health 2009, 6, 1894-1916. [CrossRef] [PubMed]

114. Tonelli, M.; Wiebe, N.; Hemmelgarn, B.; Klarenbach, S.; Field, C.; Manns, B.; Thadhani, R.; Gill, J.; The Alberta Kidney Disease Network. Trace elements in hemodialysis patients, a systematic review and meta-analysis. BMC Med. 2009, 7, 25. [CrossRef] [PubMed]

115. Rucker, D.; Thadhani, R.; Tonelli, M. Trace element status in hemodialysis patients. Semin. Dial. 2010, 23, 389-395. [CrossRef] [PubMed]

116. Shanmugam, L.; Green, S.R.; Radhakrishnan, H.; Kadavanu, T.M.; Ramachandrappa, A.; Tiwari, S.R.; Rajkumar, A.L.; Govindasamy, E. Trace Elements in Chronic Haemodialysis Patients and Healthy Individuals-A Comparative Study. J. Clin. Diagn. Res. 2016, 10, OC14-OC17. [PubMed]

117. Caglar, K.; Hakim, R.M.; Ikizler, T.A. Approaches to the reversal of malnutrition, inflammation, and atherosclerosis in end-stage renal disease. Nutr. Rev. 2002, 60, 378-387. [CrossRef] [PubMed]

118. Ikizler, T.A.; Cano, N.J.; Franch, H.; Fouque, D.; Himmelfarb, J.; Kalantar-Zadeh, K.; Kuhlmann, M.K.; Stenvinkel, P.; TerWee, P.; Teta, D.; et al. Prevention and treatment of protein energy wasting in chronic kidney disease patients: A consensus statement by the International Society of Renal Nutrition and Metabolism. Kidney Int. 2013, 84, 1096-1107. [CrossRef] [PubMed]

119. Ipema, K.J.; van der Schans, C.P.; Vonk, N.; de Vries, J.M.; Westerhuis, R.; Duym, E.; Franssen, C.F. A difference between day and night, protein intake improves after the transition from conventional to frequent nocturnal home hemodialysis. J. Ren. Nutr. 2012, 22, 365-372. [CrossRef] [PubMed]

120. Maduell, F.; Arias, M.; Durán, C.E.; Vera, M.; Fontseré, N.; Azqueta, M.; Rico, N.; Pérez, N.; Sentis, A.; Elena, M.; et al. Nocturnal, every-other-day, online haemodiafiltration: An effective therapeutic alternative. Nephrol. Dial. Transplant. 2012, 27, 1619-1631. [CrossRef] [PubMed]

121. Rocco, M.V.; Lockridge, R.S., Jr.; Beck, G.J.; Eggers, P.W.; Gassman, J.J.; Greene, T.; Larive, B.; Chan, C.T.; Chertow, G.M.; Frequent Hemodialysis Network (FHN) Trial Group. The effects of frequent nocturnal home hemodialysis, the Frequent Hemodialysis Network Nocturnal Trial. Kidney Int. 2011, 80, 1080-1091. [CrossRef] [PubMed]

122. Schorr, M.; Manns, B.J.; Culleton, B.; Walsh, M.; Klarenbach, S.; Tonelli, M.; Sauve, L.; Chin, R.; Barnieh, L.; Hemmelgarn, B.R.; et al. The effect of nocturnal and conventional hemodialysis on markers of nutritional status, results from a randomized trial. J. Ren. Nutr. 2011, 21, 271-276. [CrossRef] [PubMed]

123. Lindsay, R.M.; Daily/Nocturnal Dialysis Study Group. The London, Ontario, Daily/Nocturnal Hemodialysis Study. Semin. Dial. 2004, 17, 85-91. [CrossRef] [PubMed] 
124. Williams, A.W.; Chebrolu, S.B.; Ing, T.S.; Ting, G.; Blagg, C.R.; Twardowski, Z.J.; Woredekal, Y.; Delano, B.; Gandhi, V.C.; Kjellstrand, C.M.; et al. Early clinical, quality-of-life, and biochemical changes of "daily hemodialysis" (6 dialyses per week). Am. J. Kidney Dis. 2004, 43, 90-102. [CrossRef] [PubMed]

125. Pierratos, A. Daily (quotidian) nocturnal home hemodialysis, nine years later. Hemodial. Int. 2001, 8, 45-50. [CrossRef] [PubMed]

126. David, S.; Kümpers, P.; Eisenbach, G.M.; Haller, H.; Kielstein, J.T. Prospective evaluation of an in-centre conversion from conventional haemodialysis to an intensified nocturnal strategy. Nephrol. Dial. Transplant. 2009, 24, 2232-2240. [CrossRef] [PubMed]

127. Brady, J.P.; Hasbargen, J.A. Correction of metabolic acidosis and its effect on albumin in chronic hemodialysis patients. Am. J. Kidney Dis. 1998, 31, 35-40. [CrossRef] [PubMed]

128. Uribarri, J.; Levin, N.W.; Delmez, J.; Depner, T.A.; Ornt, D.; Owen, W.; Yan, G. Association of acidosis and nutritional parameters in hemodialysis patients. Am. J. Kidney Dis. 1999, 34, 493-499. [CrossRef]

129. Bergström, J. Metabolic acidosis and nutrition in dialysis patients. Blood Purif. 1995, 13, 361-367. [CrossRef] [PubMed]

130. Vashistha, T.; Kalantar-Zadeh, K.; Molnar, M.Z.; Torlén, K.; Mehrotra, R. Dialysis modality and correction of uremic metabolic acidosis, relationship with all-cause and cause-specific mortality. Clin. J. Am. Soc. Nephrol. 2013, 8, 254-264. [CrossRef] [PubMed]

131. Piccoli, G.; Bonello, F.; Massara, C.; Salomone, M.; Maffei, S.; Iadarola, G.M.; Stramignoni, E.; Rosati, C.; Borca, M.; Belardi, P.; et al. Death in conditions of cachexia, the price for the dialysis treatment of the elderly? Kidney Int. Suppl. 1993, 41, S282-S286. [PubMed]

132. Pecoits-Filho, R.; Lindholm, B.; Stenvinkel, P. The malnutrition, inflammation, and atherosclerosis (MIA) syndrome-The heart of the matter. Nephrol. Dial. Transplant. 2002, 17, 28-31. [CrossRef] [PubMed]

133. Quresh, A.R.; Alvestrand, A.; Divino-Filho, J.C.; Gutierrez, A.; Heimbürger, O.; Lindholm, B.; Bergström, J. Inflammation, malnutrition, and cardiac disease as predictors of mortality in hemodialysis patients. J. Am. Soc. Nephrol. 2002, 13, S28-S36.

134. Kalantar-Zadeh, K.; Kopple, J.D.; Block, G.; Humphreys, M.H. A malnutrition-inflammation score is correlated with morbidity and mortality in maintenance hemodialysis patients. Am. J. Kidney Dis. 2001, 38, 1251-1263. [CrossRef] [PubMed]

135. Kalantar-Zadeh, K.; Kopple, J.D. Relative contributions of nutrition and inflammation to clinical outcome in dialysis patients. Am. J. Kidney Dis. 2001, 38, 1343-1350. [CrossRef] [PubMed]

136. Doshi, M.; Streja, E.; Rhee, C.M.; Park, J.; Ravel, V.A.; Soohoo, M.; Moradi, H.; Lau, W.L.; Mehrotra, R.; Kuttykrishnan, S.; et al. Examining the robustness of the obesity paradox in maintenance hemodialysis patients, a marginal structural model analysis. Nephrol. Dial. Transplant. 2016, 31, 1310-1319. [CrossRef] [PubMed]

137. Kahraman, S.; Yilmaz, R.; Akinci, D.; Arici, M.; Altun, B.; Erdem, Y.; Yasavul, U.; Turgan, C. U-shaped association of body mass index with inflammation and atherosclerosis in hemodialysis patients. J. Ren. Nutr. 2005, 15, 377-386. [CrossRef] [PubMed]

138. Kwan, B.C.; Murtaugh, M.A.; Beddhu, S. Associations of body size with metabolic syndrome and mortality in moderate chronic kidney disease. Clin. J. Am. Soc. Nephrol. 2007, 2, 992-998. [CrossRef] [PubMed]

139. Beddhu, S. The body mass index paradox and an obesity, inflammation, and atherosclerosis syndrome in chronic kidney disease. Semin. Dial. 2004, 17, 229-232. [CrossRef] [PubMed]

140. Huang, J.C.; Lin, H.Y.; Lim, L.M.; Chen, S.C.; Chang, J.M.; Hwang, S.J.; Tsai, J.C.; Hung, C.C.; Chen, H.C. Body mass index, mortality, and gender difference in advanced chronic kidney disease. PLoS ONE 2015, 10, e0126668. [CrossRef] [PubMed]

141. Lentine, K.L.; Delos Santos, R.; Axelrod, D.; Schnitzler, M.A.; Brennan, D.C.; Tuttle-Newhall, J.E. Obesity and kidney transplant candidates, how big is too big for transplantation? Am. J. Nephrol. 2012, 36, 575-586. [CrossRef] [PubMed]

142. Pham, P.T.; Danovitch, G.M.; Pham, P.C. Kidney transplantation in the obese transplant candidates, to transplant or not to transplant? Semin. Dial. 2013, 26, 568-577. [CrossRef] [PubMed]

143. Orlic, L.; Mikolasevic, I.; Jakopcic, I.; Grskovic, A.; Jelic Pranjic, I.; Racki, S.; Stimac, D. Body mass index, short- and long-term impact on kidney transplantation. Int. J. Clin. Pract. 2015, 69, 1357-1365. [CrossRef] [PubMed] 
144. Kwan, J.M.; Hajjiri, Z.; Metwally, A.; Finn, P.W.; Perkins, D.L. Effect of the Obesity Epidemic on Kidney Transplantation, Obesity Is Independent of Diabetes as a Risk Factor for Adverse Renal Transplant Outcomes. PLoS ONE 2016, 11, e0165712. [CrossRef] [PubMed]

145. Camilleri, B.; Bridson, J.M.; Sharma, A.; Halawa, A. From chronic kidney disease to kidney transplantation: The impact of obesity and its treatment modalities. Transplant. Rev. 2016, 30, 203-211. [CrossRef] [PubMed]

146. Molnar, M.Z.; Streja, E.; Kovesdy, C.P.; Bunnapradist, S.; Sampaio, M.S.; Jing, J.; Krishnan, M.; Nissenson, A.R.; Danovitch, G.M.; Kalantar-Zadeh, K. Associations of body mass index and weight loss with mortality in transplant-waitlisted maintenance hemodialysis patients. Am. J. Transplant. 2011, 11, 725-736. [CrossRef] [PubMed]

147. Schold, J.D.; Srinivas, T.R.; Guerra, G.; Reed, A.I.; Johnson, R.J.; Weiner, I.D.; Oberbauer, R.; Harman, J.S.; Hemming, A.W.; Meier-Kriesche, H.U. A “weight-listing" paradox for candidates of renal transplantation? Am. J. Transplant. 2007, 7, 550-559. [CrossRef] [PubMed]

148. McClellan, W.M.; Plantinga, L.C. A public health perspective on CKD and obesity. Nephrol. Dial. Transplant. 2013, 28, iv37-iv42. [CrossRef] [PubMed]

149. Stenvinkel, P.; Zoccali, C.; Ikizler, T.A. Obesity in CKD—What should nephrologists know? J. Am. Soc. Nephrol. 2013, 24, 1727-1736. [CrossRef] [PubMed]

150. Hricik, D.E. Metabolic syndrome in kidney transplantation, management of risk factors. Clin. J. Am. Soc. Nephrol. 2011, 6, 1781-1785. [CrossRef] [PubMed]

151. Imam, T.H.; Fischer, H.; Jing, B.; Burchette, R.; Henry, S.; DeRose, S.F.; Coleman, K.J. Estimated GFR Before and After Bariatric Surgery in CKD. Am. J. Kidney Dis. 2017, 69, 380-388. [CrossRef] [PubMed]

152. Teta, D. Weight loss in obese patients with chronic kidney disease, who and how? J. Ren. Care 2010, 36, 163-171. [CrossRef] [PubMed]

153. Neel, J.V. Diabetes mellitus, a "thrifty" genotype rendered detrimental by "progress"? Am. J. Hum. Genet. 1962, 14, 353-362. [PubMed]

154. Stefan, N.; Artunc, F.; Heyne, N.; Machann, J.; Schleicher, E.D.; Häring, H.U. Obesity and renal disease, not all fat is created equal and not all obesity is harmful to the kidneys. Nephrol. Dial. Transplant. 2016, 31, 726-730. [CrossRef] [PubMed]

155. Zoccali, C.; Torino, C.; Tripepi, G.; Mallamaci, F. Assessment of obesity in chronic kidney disease, what is the best measure? Curr. Opin. Nephrol. Hypertens. 2012, 21, 641-646. [CrossRef] [PubMed]

156. Vigotti, F.N.; Teta, L.; Pia, A.; Mirasole, S.; Guzzo, G.; Giuffrida, D.; Capizzi, I.; Avagnina, P.; Ippolito, D.; Piccoli, G.B. Intensive weight loss combining flexible dialysis with a personalized, ad libitum, coach-assisted diet program. A "pilot" case series. Hemodial. Int. 2015, 19, 368-378. [CrossRef] [PubMed]

157. Young, G.A.; Parsons, F.M. Amino nitrogen loss during haemodialysis, its dietary significance and replacement. Clin. Sci. 1966, 31, 299-307. [PubMed]

158. Kurella, M.; Covinsky, K.E.; Collins, A.J.; Chertow, G.M. Octogenarians and nonagenarians starting dialysis in the United States. Ann. Intern. Med. 2007, 146, 177-183. [CrossRef] [PubMed]

159. Seckinger, J.; Dschietzig, W.; Leimenstoll, G.; Rob, P.M.; Kuhlmann, M.K.; Pommer, W.; Fraass, U.; Ritz, E.; Schwenger, V. Morbidity, mortality and quality of life in the ageing haemodialysis population, results from the ELDERLY study. Clin. Kidney J. 2016, 9, 839-848. [CrossRef] [PubMed]

160. Chauveau, P.; Combe, C.; Fouque, D.; Aparicio, M. Vegetarianism, advantages and drawbacks in patients with chronic kidney diseases. J. Ren. Nutr. 2013, 23, 399-405. [CrossRef] [PubMed]

161. Li, H.; Long, Q.; Shao, C.; Fan, H.; Yuan, L.; Huang, B.; Gu, Y.; Lin, S.; Hao, C.; Chen, J. Effect of short-term low-protein diet supplemented with keto acids on hyperphosphatemia in maintenance hemodialysis patients. Blood Purif. 2011, 31, 33-40. [CrossRef] [PubMed]

162. Jiang, N.; Qian, J.; Sun, W.; Lin, A.; Cao, L.; Wang, Q.; Ni, Z.; Wan, Y.; Linholm, B.; Axelsson, J.; Yao, Q. Better preservation of residual renal function in peritoneal dialysis patients treated with a low-protein diet supplemented with keto acids, a prospective, randomized trial. Nephrol. Dial. Transplant. 2009, 24, 2551-2558. [CrossRef] [PubMed]

163. Fissell, R.B.; Karaboyas, A.; Bieber, B.A.; Sen, A.; Li, Y.; Lopes, A.A.; Akiba, T.; Bommer, J.; Ethier, J.; Jadoul, M.; et al. Phosphate binder pill burden, patient-reported non-adherence, and mineral bone disorder markers: Findings from the DOPPS. Hemodial. Int. 2016, 20, 38-49. [CrossRef] [PubMed] 
164. Ramakrishnan, K.; Braunhofer, P.; Newsome, B.; Lubeck, D.; Wang, S.; Deuson, J.; Claxton, A.J. The economic impact of improving phosphate binder therapy adherence and attainment of guideline phosphorus goals in hemodialysis patients, a Medicare cost-offset model. Adv. Ther. 2014, 31, 1272-1286. [CrossRef] [PubMed]

165. Wang, S.; Alfieri, T.; Ramakrishnan, K.; Braunhofer, P.; Newsome, B.A. Serum phosphorus levels and pill burden are inversely associated with adherence in patients on hemodialysis. Nephrol. Dial. Transplant. 2014, 29, 2092-2099. [CrossRef] [PubMed]

166. Chiu, Y.W.; Teitelbaum, I.; Misra, M.; de Leon, E.M.; Adzize, T.; Mehrotra, R. Pill burden, adherence, hyperphosphatemia, and quality of life in maintenance dialysis patients. Clin. J. Am. Soc. Nephrol. 2009, 4, 1089-1096. [CrossRef] [PubMed]

167. St-Jules, D.E.; Woolf, K.; Pompeii, M.L.; Sevick, M.A. Exploring Problems in Following the Hemodialysis Diet and Their Relation to Energy and Nutrient Intakes: The BalanceWise Study. J. Ren. Nutr. 2016, 26, 118-124. [CrossRef] [PubMed]

168. Lindsay, R.M.; Spanner, E.; Heidenheim, R.P.; LeFebvre, J.M.; Hodsman, A.; Baird, J.; Allison, M.E. Which comes first, Kt/V or PCR-Chicken or egg? Kidney Int. Suppl. 1992, 38, S32-S36. [PubMed]

169. Lindsay, R.M.; Bergström, J. Membrane biocompatibility and nutrition in maintenance haemodialysis patients. Nephrol. Dial. Transplant. 1994, 9, 150-155. [PubMed]

170. Kloppenburg, W.D.; Stegeman, C.A.; Hovinga, T.K.; Vastenburg, G.; Vos, P.; de Jong, P.E.; Huisman, R.M. Effect of prescribing a high protein diet and increasing the dose of dialysis on nutrition in stable chronic haemodialysis patients, a randomized, controlled trial. Nephrol. Dial. Transplant. 2004, 19, 1212-1223. [CrossRef] [PubMed]

171. Locatelli, F.; Altieri, P.; Andrulli, S.; Bolasco, P.; Sau, G.; Pedrini, L.A.; Basile, C.; David, S.; Feriani, M.; Montagna, G.; et al. Hemofiltration and hemodiafiltration reduce intradialytic hypotension in ESRD. J. Am. Soc. Nephrol. 2010, 21, 1798-1807. [CrossRef] [PubMed]

172. Tsuchida, K.; Minakuchi, J. Clinical benefits of predilution on-line hemodiafiltration. Blood Purif. 2013, 35, 18-22. [CrossRef] [PubMed]

173. Masakane, I. How to prescribe hemodialysis or hemodiafiltration in order to ameliorate dialysis-related symptoms and complications. Contrib. Nephrol. 2011, 168, 53-63. [PubMed]

174. Locatelli, F.; Martin-Malo, A.; Hannedouche, T.; Loureiro, A.; Papadimitriou, M.; Wizemann, V.; Jacobson, S.H.; Czekalski, S.; Ronco, C.; Vanholder, R.; et al. Effect of membrane permeability on survival of hemodialysis patients. J. Am. Soc. Nephrol. 2009, 20, 645-654. [CrossRef] [PubMed]

175. Nubé, M.J.; Peters, S.A.; Blankestijn, P.J.; Canaud, B.; Davenport, A.; Grooteman, M.P.; Asci, G.; Locatelli, F.; Maduell, F.; HDF Pooling Project investigators. Mortality reduction by post-dilution online-haemodiafiltration: A cause-specific analysis. Nephrol. Dial. Transplant. 2016. [CrossRef]

176. Blankestijn, P.J. Haemodiafiltration, becoming the new standard? Nephrol. Dial. Transplant. 2013, $28,1-2$. [CrossRef] [PubMed]

177. Mostovaya, I.M.; Grooteman, M.P.; Basile, C.; Davenport, A.; de Roij van Zuijdewijn, C.L.; Wanner, C.; Nubé, M.J.; Blankestijn, P.J. High convection volume in online post-dilution haemodiafiltration, relevance, safety and costs. Clin. Kidney J. 2015, 8, 368-373. [CrossRef] [PubMed]

178. Canaud, B.; Bragg-Gresham, J.L.; Marshall, M.R.; Desmeules, S.; Gillespie, B.W.; Depner, T.; Klassen, P.; Port, F.K. Mortality risk for patients receiving hemodiafiltration versus hemodialysis, European results from the DOPPS. Kidney Int. 2006, 69, 2087-2093. [CrossRef] [PubMed]

179. Tsuchida, K.; Minakuchi, J. Albumin loss under the use of the high-performance membrane. Contrib. Nephrol. 2011, 173, 76-83. [PubMed]

180. Kirschbaum, B. The decline in serum albumin after conversion to high flux, high efficiency dialysis. Artif. Organs 1994, 18, 729-735. [CrossRef] [PubMed]

181. Mineshima, M. Optimal Design of Dialyzers. Contrib. Nephrol. 2017, 189, 204-209. [PubMed]

182. Ikizler, T.A. Using and interpreting serum albumin and prealbumin as nutritional markers in patients on chronic dialysis. Semin. Dial. 2014, 27, 590-592. [CrossRef] [PubMed]

183. Mittman, N.; Avram, M.M.; Oo, K.K.; Chattopadhyay, J. Serum prealbumin predicts survival in hemodialysis and peritoneal dialysis, 10 years of prospective observation. Am. J. Kidney Dis. 2001, 38, 1358-1364. [CrossRef] [PubMed] 
184. Sreedhara, R.; Avram, M.M.; Blanco, M.; Batish, R.; Avram, M.M.; Mittman, N. Prealbumin is the best nutritional predictor of survival in hemodialysis and peritoneal dialysis. Am. J. Kidney Dis. 1996, 28, 937-942. [CrossRef]

185. Martinez-Gonzalez, M.A.; Martin-Calvo, N. Mediterranean diet and life expectancy, beyond olive oil, fruits, and vegetables. Curr. Opin. Clin. Nutr. Metab. Care 2016, 19, 401-407. [CrossRef] [PubMed]

186. Tong, T.Y.; Wareham, N.J.; Khaw, K.T.; Imamura, F.; Forouhi, N.G. Prospective association of the Mediterranean diet with cardiovascular disease incidence and mortality and its population impact in a non-Mediterranean population, the EPIC-Norfolk study. BMC Med. 2016, 14, 135. [CrossRef] [PubMed]

187. Liyanage, T.; Ninomiya, T.; Wang, A.; Neal, B.; Jun, M.; Wong, M.G.; Jardine, M.; Hillis, G.S.; Perkovic, V. Effects of the Mediterranean Diet on Cardiovascular Outcomes-A Systematic Review and Meta-Analysis. PLoS ONE 2016, 11, e0159252. [CrossRef] [PubMed]

188. Hu, F.B. The Mediterranean diet and mortality-Olive oil and beyond. N. Engl. J. Med. 2003, 348, 2595-2596. [CrossRef] [PubMed]

189. Estruch, R.; Ros, E.; Salas-Salvadó, J.; Covas, M.I.; Corella, D.; Arós, F.; Gómez-Gracia, E.; Ruiz-Gutiérrez, V.; Fiol, M.; PREDIMED Study Investigators. Primary prevention of cardiovascular disease with a Mediterranean diet. N. Engl. J. Med. 2013, 368, 1279-1290. [CrossRef] [PubMed]

190. Song, M.; Fung, T.T.; Hu, F.B.; Willett, W.C.; Longo, V.D.; Chan, A.T.; Giovannucci, E.L. Association of Animal and Plant Protein Intake With All-Cause and Cause-Specific Mortality. JAMA Intern. Med. 2016, 176, 1453-1463. [CrossRef] [PubMed]

191. Wu, H.; Flint, A.J.; Qi, Q.; van Dam, R.M.; Sampson, L.A.; Rimm, E.B.; Holmes, M.D.; Willett, W.C.; Hu, F.B.; Sun, $\mathrm{Q}$. Association between dietary whole grain intake and risk of mortality, two large prospective studies in US men and women. JAMA Intern. Med. 2015, 175, 373-384. [CrossRef] [PubMed]

192. Nguyen, B.; Bauman, A.; Gale, J.; Banks, E.; Kritharides, L.; Ding, D. Fruit and vegetable consumption and all-cause mortality, evidence from a large Australian cohort study. Int. J. Behav. Nutr. Phys. Act. 2016, $13,9$. [CrossRef] [PubMed]

193. Stefler, D.; Pikhart, H.; Kubinova, R.; Pajak, A.; Stepaniak, U.; Malyutina, S.; Simonova, G.; Peasey, A.; Marmot, M.G.; Bobak, M. Fruit and vegetable consumption and mortality in Eastern Europe, Longitudinal results from the Health, Alcohol and Psychosocial Factors in Eastern Europe study. Eur. J. Prev. Cardiol. 2016, 23, 493-501. [CrossRef] [PubMed]

194. Kelly, J.T.; Palmer, S.C.; Wai, S.N.; Ruospo, M.; Carrero, J.J.; Campbell, K.L.; Strippoli, G.F. Healthy Dietary Patterns and Risk of Mortality and ESRD in CKD: A Meta-Analysis of Cohort Studies. Clin. J. Am. Soc. Nephrol. 2016. [CrossRef] [PubMed]

195. Gutiérrez, O.M.; Muntner, P.; Rizk, D.V.; McClellan, W.M.; Warnock, D.G.; Newby, P.K.; Judd, S.E. Dietary patterns and risk of death and progression to ESRD in individuals with CKD: A cohort study. Am. J. Kidney Dis. 2014, 64, 204-213. [CrossRef] [PubMed]

196. Bakris, G.L.; Pitt, B.; Weir, M.R.; Freeman, M.W.; Mayo, M.R.; Garza, D.; Stasiv, Y.; Zawadzki, R.; Berman, L.; Bushinsky, D.A. AMETHYST-DN Investigators. Effect of Patiromer on Serum Potassium Level in Patients WITH Hyperkalemia and Diabetic Kidney Disease: The AMETHYST-DN Randomized Clinical Trial. JAMA 2015, 314, 151-161. [CrossRef] [PubMed]

197. Kosiborod, M.; Rasmussen, H.S.; Lavin, P.; Qunibi, W.Y.; Spinowitz, B.; Packham, D.; Roger, S.D.; Yang, A.; Lerma, E.; Singh, B. Effect of sodium zirconium cyclosilicate on potassium lowering for 28 days among outpatients with hyperkalemia: The HARMONIZE randomized clinical trial. JAMA 2014, 312, 2223-2233. [CrossRef] [PubMed]

198. Kovesdy, C.P. Updates in hyperkalemia: Outcomes and therapeutic strategies. Rev. Endocr. Metab. Disord. 2016. [CrossRef] [PubMed]

199. Meaney, C.J.; Beccari, M.V.; Yang, Y.; Zhao, J. Systematic Review and Meta-Analysis of Patiromer and Sodium Zirconium Cyclosilicate: A New Armamentarium for the Treatment of Hyperkalemia. Pharmacotherapy 2017. [CrossRef] [PubMed]

200. Buoncristiani, U.; Quintaliani, G.; Cozzari, M.; Giombini, L.; Ragaiolo, M. Daily dialysis, long-term clinical metabolic results. Kidney Int. Suppl. 1988, 24, S137-S140. [PubMed]

201. Raj, D.S.; Charra, B.; Pierratos, A.; Work, J. In search of ideal hemodialysis, is prolonged frequent dialysis the answer? Am. J. Kidney Dis. 1999, 34, 597-610. [CrossRef] 
202. Weinhandl, E.D.; Gilbertson, D.T.; Collins, A.J. Mortality, Hospitalization, and Technique Failure in Daily Home Hemodialysis and Matched Peritoneal Dialysis Patients: A Matched Cohort Study. Am. J. Kidney Dis. 2016, 67, 98-110. [CrossRef] [PubMed]

203. Woods, J.D.; Port, F.K.; Stannard, D.; Blagg, C.R.; Held, P.J. Comparison of mortality with home hemodialysis and center hemodialysis: A national study. Kidney Int. 1996, 49, 1464-1470. [CrossRef] [PubMed]

204. Arkouche, W.; Traeger, J.; Delawari, E.; Sibaï-Galland, R.; Abdullah, E.; Galland, R.; Leitienne, P.; Fouque, D.; Laville, M. Twenty-five years of experience with out-center hemodialysis. Kidney Int. 1999, 56, 2269-2275. [CrossRef] [PubMed]

205. Ting, G.O.; Kjellstrand, C.; Freitas, T.; Carrie, B.J.; Zarghamee, S. Long-term study of high-comorbidity ESRD patients converted from conventional to short daily hemodialysis. Am. J. Kidney Dis. 2003, 42, 1020-1035. [CrossRef] [PubMed]

206. Puñal, J.; Lema, L.V.; Sanhez-Guisande, D.; Ruano-Ravina, A. Clinical effectiveness and quality of life of conventional haemodialysis versus short daily haemodialysis, a systematic review. Nephrol. Dial. Transplant. 2008, 23, 2634-2646. [CrossRef] [PubMed]

207. Piccoli, G.B.; Ferraresi, M.; Consiglio, V.; Scognamiglio, S.; Deagostini, M.C.; Randone, O.; Vigotti, F.N.; Calderale, P.M. Why home hemodialysis? A systematic "marketing" analysis. J. Nephrol. 2012, 25, 159-169. [CrossRef] [PubMed]

208. Cornelis, T.; Kotanko, P.; Goffin, E.; Kooman, J.P.; van der Sande, F.M.; Chan, C.T. Can intensive hemodialysis prevent loss of functionality in the elderly ESRD patient? Semin. Dial. 2011, 24, 645-652. [CrossRef] [PubMed]

209. Piccoli, G.B.; Mezza, E.; Quaglia, M.; Bermond, F.; Bechis, F.; Burdese, M.; Gai, M.; Pacitti, A.; Jeantet, A.; Segoloni, G.P.; Piccoli, G. Flexibility as an implementation strategy for a daily dialysis program. J. Nephrol. 2003, 16, 365-372. [PubMed]

210. Takahashi, S. Future home hemodialysis-Advantages of the NxStage System One. Contrib. Nephrol. 2012, 177, 117-126. [PubMed]

211. Buoncristiani, U.; Giombini, L.; Cozzari, M.; Carobi, C.; Quintaliani, G.; Brugnano, R. Daily recycled bicarbonate dialysis with polyacrylonitrile. Trans. Am. Soc. Artif. Intern. Organs 1983, 29, 669-672. [PubMed]

212. Lockridge, R.S., Jr.; Pipkin, M. Short and long nightly hemodialysis in the United States. Hemodial. Int. 2008, 12, S48-S50. [CrossRef] [PubMed]

213. Sachdeva, M.; Barta, V.; Thakkar, I.; Sakhiya, V.; Miller, I. Pregnancy outcomes in women on hemodialysis, a national survey. Clin. Kidney J. 2017. [CrossRef]

214. Vilar, E.; Fry, A.C.; Wellsted, D.; Tattersall, J.E.; Greenwood, R.N.; Farrington, K. Long-term outcomes in online hemodiafiltration and high-flux hemodialysis, a comparative analysis. Clin. J. Am. Soc. Nephrol. 2009, 4, 1944-1953. [CrossRef] [PubMed]

215. Panichi, V.; Rizza, G.M.; Paoletti, S.; Bigazzi, R.; Aloisi, M.; Barsotti, G.; Rindi, P.; Donati, G.; Antonelli, A.; Panicucci, E.; et al. Chronic inflammation and mortality in haemodialysis, effect of different renal replacement therapies. Results from the RISCAVID study. Nephrol. Dial. Transplant. 2008, 23, 2337-2343. [CrossRef] [PubMed]

216. Siriopol, D.; Canaud, B.; Stuard, S.; Mircescu, G.; Nistor, I.; Covic, A. New insights into the effect of haemodiafiltration on mortality, the Romanian experience. Nephrol Dial. Transplant. 2015, 30, $294-301$. [CrossRef] [PubMed]

217. Maduell, F.; Moreso, F.; Pons, M.; Ramos, R.; Mora-Macià, J.; Carreras, J.; Soler, J.; Torres, F.; Campistol, J.M.; Martinez-Castelao, A.; et al. High-efficiency postdilution online haemodiafiltration reduces all-cause mortality in haemodialysis patients. J. Am. Soc. Nephrol. 2013, 24, 487-497. [CrossRef] [PubMed]

218. Grooteman, M.P.; van den Dorpel, M.A.; Bots, M.L.; Penne, E.L.; van der Weerd, N.C.; Mazairac, A.H.; den Hoedt, C.H.; van der Tweel, I.; Lévesque, R.; Nubé, M.J.; et al. Effect of online hemodiafiltration on all-cause mortality and cardiovascular outcomes. J. Am. Soc. Nephrol. 2012, 23, 1087-1096. [CrossRef] [PubMed]

219. Nistor, I.; Palmer, S.C.; Craig, J.C.; Saglimbene, V.; Vecchio, M.; Covic, A.; Strippoli, G.F. Haemodiafiltration, haemofiltration and haemodialysis for end-stage kidney disease. Cochrane Database Syst. Rev. 2015, 5, CD006258.

220. Lornoy, W.; Becaus, I.; Billiouw, J.M.; Sierens, L.; Van Malderen, P.; D’Haenens, P. On-line haemodiafiltration, Remarkable removal of beta2-microglobulin-Long-term clinical observations. Nephrol. Dial. Transplant. 2000, 15, 49-54. [CrossRef] [PubMed]

221. Tattersall, J. Clearance of beta-2-microglobulin and middle molecules in haemodiafiltration. Contrib. Nephrol. 2007, 158, 201-209. [PubMed] 
222. Borrelli, S.; Minutolo, R.; de Nicola, L.; De Simone, E.; De Simone, W.; Zito, B.; Guastaferro, P.; Nigro, F.; Iulianiello, G.; Credentino, O.; et al. Effect of hemodiafiltration with endogenous reinfusion on overt idiopathic chronic inflammation in maintenance hemodialysis patients, a multicenter longitudinal study. Hemodial. Int. 2014, 18, 758-766. [CrossRef] [PubMed]

223. Winchester, J.F.; Salsberg, J.A.; Levin, N.W. Beta-2 microglobulin in ESRD, an in-depth review. Adv. Ren. Replace Ther. 2003, 10, 279-309. [CrossRef] [PubMed]

224. Canaud, B. Effect of online hemodiafiltration on morbidity and mortality of chronic kidney disease patients. Contrib. Nephrol. 2007, 158, 216-224. [PubMed]

225. Akizawa, T.; Koiwa, F. Clinical Expectation of Online Hemodiafiltration: A Japanese Perspective. Blood Purif. 2015, 40, 12-16. [CrossRef] [PubMed]

226. Masakane, I.; Esashi, S.; Igarashi, H. Biocompatibility of predilution on-line hemodiafiltration. Blood Purif. 2013, 35, 34-38. [CrossRef] [PubMed]

227. Rosansky, S.J.; Clark, W.F.; Eggers, P.; Glassock, R.J. Initiation of dialysis at higher GFRs: Is the apparent rising tide of early dialysis harmful or helpful? Kidney Int. 2009, 76, 257-261. [CrossRef] [PubMed]

228. Cooper, B.A.; Branley, P.; Bulfone, L.; Collins, J.F.; Craig, J.C.; Fraenkel, M.B.; Harris, A.; Johnson, D.W.; Kesselhut, J.; IDEAL Study. A randomized, controlled trial of early versus late initiation of dialysis. N. Engl. J. Med. 2010, 363, 609-619. [CrossRef] [PubMed]

229. Nesrallah, G.E.; Mustafa, R.A.; Clark, W.F.; Bass, A.; Barnieh, L.; Hemmelgarn, B.R.; Klarenbach, S.; Quinn, R.R.; Hiremath, S.; Canadian Society of Nephrology. Canadian Society of Nephrology 2014 clinical practice guideline for timing the initiation of chronic dialysis. CMAJ 2014, 186, 112-117. [CrossRef] [PubMed]

230. Crews, D.C.; Scialla, J.J.; Boulware, L.E.; Navaneethan, S.D.; Nally, J.V., Jr.; Liu, X.; Arrigain, S.; Schold, J.D.; Ephraim, P.L.; DEcIDE Network Patient Outcomes in End Stage Renal Disease Study Investigators. Comparative effectiveness of early versus conventional timing of dialysis initiation in advanced CKD. Am. J. Kidney Dis. 2014, 63, 806-815. [CrossRef] [PubMed]

231. Obi, Y.; Streja, E.; Rhee, C.M.; Ravel, V.; Amin, A.N.; Cupisti, A.; Chen, J.; Mathew, A.T.; Kovesdy, C.P.; Mehrotra, R.; et al. Incremental Hemodialysis, Residual Kidney Function, and Mortality Risk in Incident Dialysis Patients: A Cohort Study. Am. J. Kidney Dis. 2016, 68, 256-265. [CrossRef] [PubMed]

232. Mathew, A.T.; Fishbane, S.; Obi, Y.; Kalantar-Zadeh, K. Preservation of residual kidney function in hemodialysis patients, reviving an old concept. Kidney Int. 2016, 90, 262-271. [CrossRef] [PubMed]

233. Borràs Sans, M.; Chacón Camacho, A.; Cerdá Vilaplana, C.; Usón Nuño, A.; Fernández, E. Incremental peritoneal dialysis, clinical outcomes and residual kidney function preservation. Nefrologia 2016, 36, $299-303$. [CrossRef] [PubMed]

234. Golper, T.A. Incremental Hemodialysis: How I Do It. Semin. Dial. 2016, 29, 476-480. [CrossRef] [PubMed]

235. Mathew, A.; Obi, Y.; Rhee, C.M.; Chen, J.L.; Shah, G.; Lau, W.L.; Kovesdy, C.P.; Mehrotra, R.; Kalantar-Zadeh, K. Treatment frequency and mortality among incident hemodialysis patients in the United States comparing incremental with standard and more frequent dialysis. Kidney Int. 2016, 90, 1071-1079. [CrossRef] [PubMed]

236. Caria, S.; Cupisti, A.; Sau, G.; Bolasco, P. The incremental treatment of ESRD, a low-protein diet combined with weekly hemodialysis may be beneficial for selected patients. BMC Nephrol. 2014, 15, 172. [CrossRef] [PubMed]

237. Bolasco, P.; Cupisti, A.; Locatelli, F.; Caria, S.; Kalantar-Zadeh, K. Dietary Management of Incremental Transition to Dialysis Therapy, Once-Weekly Hemodialysis Combined With Low-Protein Diet. J. Ren. Nutr. 2016, 26, 352-359. [CrossRef] [PubMed]

238. Obi, Y.; Eriguchi, R.; Ou, S.M.; Rhee, C.M.; Kalantar-Zadeh, K. What Is Known and Unknown about Twice-Weekly Hemodialysis. Blood Purif. 2015, 40, 298-305. [CrossRef] [PubMed]

239. Davenport, A. Will incremental hemodialysis preserve residual function and improve patient survival? Semin. Dial. 2015, 28, 16-19. [CrossRef] [PubMed]

240. Kalantar-Zadeh, K.; Unruh, M.; Zager, P.G.; Kovesdy, C.P.; Bargman, J.M.; Chen, J.; Sankarasubbaiyan, S.; Shah, G.; Golper, T.; Sherman, R.A.; et al. Twice-weekly and incremental hemodialysis treatment for initiation of kidney replacement therapy. Am. J. Kidney Dis. 2014, 64, 181-186. [CrossRef] [PubMed]

241. Kalantar-Zadeh, K.; Casino, F.G. Let us give twice-weekly hemodialysis a chance, revisiting the taboo. Nephrol. Dial. Transplant. 2014, 29, 1618-1620. [CrossRef] [PubMed] 
242. Davenport, A. Is Hemodialysis Patient Survival Dependent upon Small Solute Clearance (Kt/V)? If So How Can Kt/V be Adjusted to Prevent under Dialysis in Vulnerable Groups? Semin. Dial. 2017. [CrossRef] [PubMed]

243. Jhamb, M.; McNulty, M.L.; Ingalsbe, G.; Childers, J.W.; Schell, J.; Conroy, M.B.; Forman, D.E.; Hergenroeder, A.; Dew, M.A. Knowledge, barriers and facilitators of exercise in dialysis patients, a qualitative study of patients, staff and neprologists. BMC Nephrol. 2016, 17, 192. [CrossRef] [PubMed]

244. Martin-Alemañy, G.; Valdez-Ortiz, R.; Olvera-Soto, G.; Gomez-Guerrero, I.; Aguire-Esquivel, G.; Cantu-Quintanilla, G.; Lopez-Alvarenga, J.C.; Miranda-Alatriste, P.; Espinosa-Cuevas, A. The effects of resistance exercise and oral nutritional supplementation during hemodialysis on indicators of nutritional status and quality of life. Nephrol. Dial. Transplant. 2016, 31, 1712-1720. [CrossRef] [PubMed]

245. Magnard, J.; Deschamps, T.; Cornu, C.; Paris, A.; Hristea, D. Effects of a six-month intradialytic physical ACTIvity program and adequate NUTritional support on protein-energy wasting, physical functioning and quality of life in chronic hemodialysis patients, ACTINUT study protocol for a randomised controlled trial. BMC Nephrol. 2013, 14, 259. [CrossRef] [PubMed]

246. Hristea, D.; Deschamps, T.; Paris, A.; Lefrançois, G.; Collet, V.; Savoiu, C.; Ozenne, S.; Coupel, S.; Testa, A.; Magnard, J. Combining intra-dialytic exercise and nutritional supplementation in malnourished older haemodialysis patients, Towards better quality of life and autonomy. Nephrology 2016, 21, 785-790. [CrossRef] [PubMed]

247. Bennett, P.N.; Daly, R.M.; Fraser, S.F.; Haines, T.; Barnard, R.; Ockerby, C.; Kent, B. The impact of an exercise physiologist coordinated resistance exercise program on the physical function of people receiving hemodialysis: A stepped wedge randomised control study. BMC Nephrol. 2013, 14, 204. [CrossRef] [PubMed]

248. Bennett, P.N.; Fraser, S.; Barnard, R.; Haines, T.; Ockerby, C.; Street, M.; Wang, W.C.; Daly, R. Effects of an intradialytic resistance training programme on physical function: A prospective stepped-wedge randomized controlled trial. Nephrol. Dial. Transplant. 2016, 31, 1302-1309. [CrossRef] [PubMed]

249. Chan, D.; Green, S.; Fiatarone Singh, M.; Barnard, R.; Cheema, B.S. Development, feasibility, and efficacy of a customized exercise device to deliver intradialytic resistance training in patients with end stage renal disease, Non-randomized controlled crossover trial. Hemodial. Int. 2016, 20, 650-660. [CrossRef] [PubMed]

250. Capitanini, A.; Lange, S.; D’Alessandro, C.; Salotti, E.; Tavolaro, A.; Baronti, M.E.; Giannese, D.; Cupisti, A. Dialysis exercise team, the way to sustain exercise programs in hemodialysis patients. Kidney Blood Press Res. 2014, 39, 129-133. [CrossRef] [PubMed]

251. Cupisti, A.; D'Alessandro, C.; Fumagalli, G.; Vigo, V.; Meola, M.; Cianchi, C.; Egidi, M.F. Nutrition and physical activity in CKD patients. Kidney Blood Press Res. 2014, 39, 107-113. [CrossRef] [PubMed]

252. Dong, J.; Ikizler, T.A. New insights into the role of anabolic interventions in dialysis patients with protein energy wasting. Curr. Opin. Nephrol. Hypertens. 2009, 18, 469-475. [CrossRef] [PubMed]

253. Lawrence, I.G.; Price, D.E.; Howlett, T.A.; Harris, K.P.; Feehally, J.; Walls, J. Erythropoietin and sexual dysfunction. Nephrol. Dial. Transplant. 1997, 12, 741-747. [CrossRef] [PubMed]

254. Collister, D.; Komenda, P.; Hiebert, B.; Gunasekara, R.; Xu, Y.; Eng, F.; Lerner, B.; Macdonald, K.; Rigatto, C.; Tangri, N. The Effect of Erythropoietin-Stimulating Agents on Health-Related Quality of Life in Anemia of Chronic Kidney Disease: A Systematic Review and Meta-analysis. Ann. Intern. Med. 2016, 164, 472-478. [CrossRef] [PubMed]

255. Xu, G.; Yan, W.; Li, J. An update for the controversies and hypotheses of regulating nonthyroidal illness syndrome in chronic kidney diseases. Clin. Exp. Nephrol. 2014, 18, 837-843. [CrossRef] [PubMed]

256. Palmer, B.F.; Clegg, D.J. Gonadal dysfunction in chronic kidney disease. Rev. Endocr. Metab. Disord. 2016. [CrossRef] [PubMed]

257. Johansen, K.L.; Mulligan, K.; Schambelan, M. Anabolic effects of nandrolone decanoate in patients receiving dialysis: A randomized controlled trial. JAMA 1999, 281, 1275-1281. [CrossRef] [PubMed]

258. Johansen, K.L.; Painter, P.L.; Sakkas, G.K.; Gordon, P.; Doyle, J.; Shubert, T. Effects of resistance exercise training and nandrolone decanoate on body composition and muscle function among patients who receive hemodialysis: A randomized, controlled trial. J. Am. Soc. Nephrol. 2006, 17, 2307-2314. [CrossRef] [PubMed]

259. Supasyndh, O.; Satirapoj, B.; Aramwit, P.; Viroonudomphol, D.; Chaiprasert, A.; Thanachatwej, V.; Vanichakarn, S.; Kopple, J.D. Effect of oral anabolic steroid on muscle strength and muscle growth in hemodialysis patients. Clin. J. Am. Soc. Nephrol. 2013, 8, 271-279. [CrossRef] [PubMed] 
260. Stenvinkel, P.; Carrero, J.J.; von Walden, F.; Ikizler, T.A.; Nader, G.A. Muscle wasting in end-stage renal disease promulgates premature death, established, emerging and potential novel treatment strategies. Nephrol. Dial. Transplant. 2016, 31, 1070-1077. [CrossRef] [PubMed]

261. Mehls, O.; Tönshoff, B.; Blum, W.F.; Heinrich, U.; Seidel, C. Growth hormone and insulin-like growth factor I in chronic renal failure-Pathophysiology and rationale for growth hormone treatment. Acta Paediatr. Scand. Suppl. 1990, 370, 28-34. [CrossRef] [PubMed]

262. Blake, P.G. Growth hormone and malnutrition in dialysis patients. Perit. Dial. Int. 1995, 15, 210-216. [PubMed]

263. Ikizler, T.A.; Wingard, R.L.; Hakim, R.M. Interventions to treat malnutrition in dialysis patients, the role of the dose of dialysis, intradialytic parenteral nutrition, and growth hormone. Am. J. Kidney Dis. 1995, 26, 256-265. [CrossRef]

264. Iglesias, P.; Díez, J.J.; Fernández-Reyes, M.J.; Aguilera, A.; Burgués, S.; Martínez-Ara, J.; Miguel, J.L.; Gómez-Pan, A.; Selgas, R. Recombinant human growth hormone therapy in malnourished dialysis patients: A randomized controlled study. Am. J. Kidney Dis. 1998, 32, 454-463. [CrossRef] [PubMed]

265. Ericsson, F.; Filho, J.C.; Lindgren, B.F. Growth hormone treatment in hemodialysis patients-A randomized, double-blind, placebo-controlled study. Scand. J. Urol. Nephrol. 2004, 38, 340-347. [CrossRef] [PubMed]

266. Kopple, J.D.; Cheung, A.K.; Christiansen, J.S.; Djurhuus, C.B.; El Nahas, M.; Feldt-Rasmussen, B.; Lange, M.; Mitch, W.E.; Wanner, C.; Wiedemann, J.; et al. OPPORTUNITY: A randomized clinical trial of growth hormone on outcome in hemodialysis patients. Clin. J. Am. Soc. Nephrol. 2008, 3, 1741-1751. [CrossRef] [PubMed]

267. Kopple, J.D.; Cheung, A.K.; Christiansen, J.S.; Djurhuus, C.B.; El Nahas, M.; Feldt-Rasmussen, B.; Mitch, W.E.; Wanner, C.; Göthberg, M.; Ikizler, T.A. OPPORTUNITY: A large-scale randomized clinical trial of growth hormone in hemodialysis patients. Nephrol. Dial. Transplant. 2011, 26, 4095-4103. [CrossRef] [PubMed]

268. Garagarza, C.A.; Valente, A.T.; Oliveira, T.S.; Caetano, C.G. Effect of personalized nutritional counseling in maintenance hemodialysis patients. Hemodial. Int. 2015, 19, 412-418. [CrossRef] [PubMed]

269. Kim, H.; Lim, H.; Choue, R. A Better Diet Quality is Attributable to Adequate Energy Intake in Hemodialysis Patients. Clin. Nutr. Res. 2015, 4, 46-55. [CrossRef] [PubMed]

270. Karavetian, M.; de Vries, N.; Rizk, R.; Elzein, H. Dietary educational interventions for management of hyperphosphatemia in hemodialysis patients, a systematic review and meta-analysis. Nutr. Rev. 2014, 72, 471-482. [CrossRef] [PubMed]

271. Bossola, M.; Leo, A.; Viola, A.; Carlomagno, G.; Monteburini, T.; Cenerelli, S.; Santarelli, S.; Boggi, R.; Miggiano, G.; Vulpio, C.; et al. Dietary intake of macronutrients and fiber in Mediterranean patients on chronic hemodialysis. J. Nephrol. 2013, 26, 912-918. [CrossRef] [PubMed]

272. Khoueiry, G.; Waked, A.; Goldman, M.; El-Charabaty, E.; Dunne, E.; Smith, M.; Kleiner, M.; Lafferty, J.; Kalantar-Zadeh, K.; El-Sayegh, S. Dietary intake in hemodialysis patients does not reflect a heart healthy diet. J. Ren. Nutr. 2011, 21, 438-447. [CrossRef] [PubMed]

273. Shah, A.; Bross, R.; Shapiro, B.B.; Morrison, G.; Kopple, J.D. Dietary energy requirements in relatively healthy maintenance hemodialysis patients estimated from long-term metabolic studies. Am. J. Clin. Nutr. 2016, 103, 757-765. [CrossRef] [PubMed]

274. Kato, A.; Ishida, J.; Endo, Y.; Takita, T.; Furuhashi, M.; Maruyama, Y.; Odamaki, M. Association of abdominal visceral adiposity and thigh sarcopenia with changes of arteriosclerosis in haemodialysis patients. Nephrol. Dial. Transplant. 2011, 26, 1967-1976. [CrossRef] [PubMed]

275. Honda, H.; Qureshi, A.R.; Axelsson, J.; Heimburger, O.; Suliman, M.E.; Barany, P.; Stenvinkel, P.; Lindholm, B. Obese sarcopenia in patients with end-stage renal disease is associated with inflammation and increased mortality. Am. J. Clin. Nutr. 2007, 86, 633-638. [PubMed]

276. Kistler, B.M.; Fitschen, P.J.; Ikizler, T.A.; Wilund, K.R. Rethinking the restriction on nutrition during hemodialysis treatment. J. Ren. Nutr. 2015, 25, 81-87. [CrossRef] [PubMed]

277. Kalantar-Zadeh, K.; Ikizler, T.A. Let them eat during dialysis, an overlooked opportunity to improve outcomes in maintenance hemodialysis patients. J. Ren. Nutr. 2013, 23, 157-163. [CrossRef] [PubMed]

278. Kistler, B.; Benner, D.; Burgess, M.; Stasios, M.; Kalantar-Zadeh, K.; Wilund, K.R. To eat or not to eat-international experiences with eating during hemodialysis treatment. J. Ren. Nutr. 2014, 24, 349-352. [CrossRef] [PubMed]

279. Sabatino, A.; Regolisti, G.; Karupaiah, T.; Sahathevan, S.; Sadu Singh, B.K.; Khor, B.H.; Salhab, N.; Karavetian, M.; Cupisti, A.; Fiaccadori, E. Protein-energy wasting and nutritional supplementation in patients with end-stage renal disease on hemodialysis. Clin. Nutr. 2016. [CrossRef] [PubMed] 
280. Beddhu, S.; Filipowicz, R.; Chen, X.; Neilson, J.L.; Wei, G.; Huang, Y.; Greene, T. Supervised oral protein supplementation during dialysis in patients with elevated C-reactive protein levels, a two phase, longitudinal, single center, open labeled study. BMC Nephrol. 2015, 16, 87. [CrossRef] [PubMed]

281. Fukuda, S.; Koyama, H.; Kondo, K.; Fujii, H.; Hirayama, Y.; Tabata, T.; Okamura, M.; Yamakawa, T.; Okada, S.; Hirata, S.; et al. Effects of nutritional supplementation on fatigue, and autonomic and immune dysfunction in patients with end-stage renal disease: A randomized, double-blind, placebo-controlled, multicenter trial. PLOS ONE 2015, 10, e0119578. [CrossRef] [PubMed]

282. Tomayko, E.J.; Kistler, B.M.; Fitschen, P.J.; Wilund, K.R. Intradialytic protein supplementation reduces inflammation and improves physical function in maintenance hemodialysis patients. J. Ren. Nutr. 2015, 25, 276-283. [CrossRef] [PubMed]

283. Maduro, I.P.; Nonino, C.B.; Sakamoto, L.M.; Meirelles, M.G.; Cardeal Da Costa, J.A.; Marchini, J.S. Red meat snacks for chronic hemodialysis patients, effect on inflammatory activity (a pilot study). Ren. Fail. 2013, 35, 830-834. [CrossRef] [PubMed]

284. Siefker, K.; DiSilvestro, R.A. Safety and antioxidant effects of a modest soy protein intervention in hemodialysis patients. J. Med. Food 2006, 9, 368-372. [CrossRef] [PubMed]

285. Chen, S.T.; Ferng, S.H.; Yang, C.S.; Peng, S.J.; Lee, H.R.; Chen, J.R. Variable effects of soy protein on plasma lipids in hyperlipidemic and normolipidemic hemodialysis patients. Am. J. Kidney Dis. 2005, 46, 1099-1106. [CrossRef] [PubMed]

286. Weiner, D.E.; Kapoian, T.; Johnson, D.S. Nutrition, vitamin D, and health outcomes in hemodialysis, time for a feeding frenzy? Curr. Opin. Nephrol. Hypertens. 2015, 24, 546-556. [CrossRef] [PubMed]

287. Pupim, L.B.; Majchrzak, K.M.; Flakoll, P.J.; Ikizler, T.A. Intradialytic oral nutrition improves protein homeostasis in chronic hemodialysis patients with deranged nutritional status. J. Am. Soc. Nephrol. 2006, 17, 3149-3157. [CrossRef] [PubMed]

288. Lacson, E., Jr.; Wang, W.; Zebrowski, B.; Wingard, R.; Hakim, R.M. Outcomes associated with intradialytic oral nutritional supplements in patients undergoing maintenance hemodialysis: A quality improvement report. Am. J. Kidney Dis. 2012, 60, 591-600. [CrossRef] [PubMed]

289. Weiner, D.E.; Tighiouart, H.; Ladik, V.; Meyer, K.B.; Zager, P.G.; Johnson, D.S. Oral intradialytic nutritional supplement use and mortality in hemodialysis patients. Am. J. Kidney Dis. 2014, 63, 276-285. [CrossRef] [PubMed]

290. Dukkipati, R.; Kalantar-Zadeh, K.; Kopple, J.D. Is there a role for intradialytic parenteral nutrition? A review of the evidence. Am. J. Kidney Dis. 2010, 55, 352-364. [CrossRef] [PubMed]

291. Dong, J.; Li, Y.J.; Xu, R.; Ikizler, T.A.; Wang, H.Y. Ketoacid Supplementation Partially Improves Metabolic Parameters in Patients on Peritoneal Dialysis. Perit. Dial. Int. 2015, 35, 736-742. [CrossRef] [PubMed]

292. Serna-Thomé, M.G.; Padilla-Rosciano, A.E.; Suchil-Bernal, L. Practical aspects of intradialytic nutritional support. Curr. Opin. Clin. Nutr. Metab. Care 2002, 5, 293-296. [CrossRef] [PubMed]

293. Nongnuch, A.; Assanatham, M.; Panorchan, K.; Davenport, A. Strategies for preserving residual renal function in peritoneal dialysis patients. Clin. Kidney J. 2015, 8, 202-211. [CrossRef] [PubMed]

294. Sigrist, M.K.; Levin, A.; Tejani, A.M. Systematic review of evidence for the use of intradialytic parenteral nutrition in malnourished hemodialysis patients. J. Ren. Nutr. 2010, 20,1-7. [CrossRef] [PubMed]

295. Marsen, T.A.; Beer, J.; Mann, H.; German IDPN-Trial Group. Intradialytic parenteral nutrition in maintenance hemodialysis patients suffering from protein-energy wasting. Results of a multicenter, open, prospective, randomized trial. Clin. Nutr. 2017, 36, 107-117. [CrossRef] [PubMed]

(C) 2017 by the authors. Licensee MDPI, Basel, Switzerland. This article is an open access article distributed under the terms and conditions of the Creative Commons Attribution (CC BY) license (http:/ / creativecommons.org/licenses/by/4.0/). 